\title{
Adsorption and Corrosion Performance of New Cationic Gemini Surfactants Derivatives of Fatty Amido Ethyl Aminium Chloride with Ester Spacer for Mild Steel in Acidic Solutions
}

\author{
Nashwa S. Bin-Hudayb ${ }^{1}$, Entsar E. Badr ${ }^{2, *}$ and M.A. Hegazy ${ }^{3, *(1)}$ \\ 1 Department of Chemistry, College of Science, Qassim University, 52318 Qassim, Saudi Arabia; \\ 371217399@qu.edu.sa \\ 2 Department of Chemistry, Faculty of Science Girls Branch, Al-Azhar University, 11754 Cairo, Egypt \\ 3 Egyptian Petroleum Research Institute (EPRI), Nasr, 11727 Cairo, Egypt \\ * Correspondence: entsar@azhar.edu.eg (E.E.B.); mohamedhegazy997@gmail.com (M.A.H.)
}

Received: 16 May 2020; Accepted: 9 June 2020; Published: 20 June 2020

\begin{abstract}
Three new cationic gemini surfactants with ester spacer type 2-2'-(ethane-1,2-diyl bis(oxy)) bis(N-(2-alkanamidoethyl)-N,N-dimethyl-2-oxoethan-1-aminium)) dichloride) (CGSES12, CGSES14 and CGSES16), based on $N, N$-dimethyl fatty amido ethylamine, were produced. These gemini quaternary ammonium salts were synthesized using a three-step reaction method, starting from the condensation of the fatty acid chloride (RCOCl) of various hydrophobic chain lengths $\left(\mathrm{R}, \mathrm{C}_{11} \mathrm{H}_{23}\right.$, $\mathrm{C}_{13} \mathrm{H}_{27}, \mathrm{C}_{15} \mathrm{H}_{31}$ ) with $\mathrm{N}, \mathrm{N}$-dimethyl ethylene diamine, followed by the quaternization of the tertiary amino group formed with the spacer of the ester group formed in the second step. The chemical configuration of the surfactants was established by FT-IR, ${ }^{1} \mathrm{HNMR},{ }^{13} \mathrm{CNMR}$ and Mass spectroscopies. The inhibition performance of three surfactants was studied by weight loss and electrochemical measurements. The results show that CGSES12, CGSES14 and CGSES16 behave as effective inhibitors and surface agents. The maximum efficiency was higher than $94 \%$ at $2.5 \mathrm{mM}$, and the inhibition order was CGSES16 > CGSES14 > CGSES12. This was due to the increment in hydrophobicity of the gemini surfactants. Their adsorption on a mild steel surface followed the Langmuir isotherm. CGSES12, CGSES14 and CGSES16 can be considered mixed-type inhibitors. The presence of CGSES12, CGSES14 and CGSES16 increased charge transfer resistance and decreased the corrosion rate. The adsorption focused on heteroatoms and the surface properties of cationic gemini surfactants.
\end{abstract}

Keywords: cationic gemini surfactants; mild steel; inhibition; EIS; Tafel; weight loss

\section{Introduction}

In the petroleum industry, mild steel (MS) is used in production pipelines, flooding systems, storage tanks, production stations, heat exchangers, and so on as a construction material [1-3]. MS is chosen for these applications due to its mechanical properties and cheap price compared to other metals like copper, aluminum, etc. [4-6]. But the main problem in using MS in the industry is corrosion, especially in industrial processes that used acids for, e.g., industrial cleaning or the acidization of petroleum wells $[7,8]$. The cost of metallic loss treatment adds to production expenses. Theref ore, the protection of MS against metallic loss is important to reduce costs [9,10]. The application of cationic surfactants as corrosion inhibitors decreases the economic burden of mild steel corrosion [11-15]. A literature review shows that cationic surfactants are added in small quantities to acidic solutions to inhibit MS dissolution [16-18]. The cost of treatment with surfactants is much lower than that of ordinary organic compounds [19-21] because the surfactant molecules move completely from the bulk 
of the solution to interface between MS and the acidic media when their concentration is less than the critical micelle concentration [22-24].

The objective of this study is the synthesis of new cationic gemini surfactants derivatives of fatty amido ethyl aminium chloride with ester spacers, and their application as corrosion inhibitors for MS in 1 $\mathrm{M} \mathrm{HCl}$. The structures of the three synthesized cationic gemini surfactants, namely 2-2'-(ethane-1,2-diyl bis(oxy)) bis(N-(2-dodecanamidoethyl)-N,N-dimethyl-2-oxoethan-1-aminium)) dichloride (CGSES12), 2-2' -(ethane-1,2-diyl bis(oxy)) bis(N-(2-tetradecanamidoethyl)-N,N-dimethyl-2-oxoethan-1-aminium)) dichloride (CGSES14) and 2-2' -(ethane-1,2-diyl bis(oxy))bis(N-(2-hexadecanamidoethyl)-N,N-dimethyl -2-oxoethan-1-aminium)) dichloride (CGSES16), were elucidated by FT-IR, ${ }^{1} \mathrm{HNMR},{ }^{13} \mathrm{CNMR}$ and Mass spectroscopies. Their inhibition effect was examined by gravimetric (weight loss), electrochemical impedance spectroscopy (EIS) and potentiodynamic polarization (PP) analysis. The adsorption thermodynamics of the inhibitors and the activation energy of MS dissolution were calculated and discussed to get information regarding corrosion inhibition based on the chemical structure of the surfactants.

\section{Materials and Methods}

\subsection{Synthesis}

The three-step method for the synthesis of the gemini surfactants with ester spacer (CGSES12, CGSES14, and CGSES16) is described in Scheme 1.

\section{Step 1}<smiles>[R]C(=O)NCCN(C)C</smiles>

Step 2<smiles>O=C(CCl)OCCOC(=O)CCl</smiles>

Step 3<smiles></smiles><smiles>[R]CC[N+](C)(C)CC(=O)OCCOC(=O)C[N+](C)(C)CCNC([R])=O</smiles>

$(\mathrm{m}=11$ CGSES12, $\mathrm{m}=13$ CGSES14, $\mathrm{m}=15$ CGSES16 )

Scheme 1. Synthesis of cationic gemini surfactants containing amide and ester group (CGSES12, CGSES14 and CGSES16). 
- Synthesis of N-(2-(dimethylamino)ethyl)dodecanamide (DAEA12)

Dodecanoyl chloride $(18.17 \mathrm{~g}, 0.0831 \mathrm{~mol})$ was added to a solution of $\mathrm{N}, \mathrm{N}$-dimethylethylendiamine $2(24.24 \mathrm{~g}, 0.275 \mathrm{~mol})$ in $150 \mathrm{~mL}$ anhydrous diethyl ether at $35-40{ }^{\circ} \mathrm{C}$. The reaction was agitated for $2 \mathrm{~h}$; then, the solvent was removed under reduced pressure. The subsequent product was washed with water, filtered off as a white solid and recrystallized using absolute ethanol. The final result was vacuum-dried [25].

Tetradecanoyl and Hexadecanoyl derivatives DAEA14; 16 were prepared similarly.

- Synthesis of the ester spacer (Ethane-1,2-diyl bis(2-chloroethanoate) (ES) The Gao method was used to synthesize ethane-1,2-diyl bis(2-chloroethanoate) [26].

- Synthesis of 2-2'-(Ethane-1,2-diylbis(oxy)) bis(N-(2-alkanamidoethyl)-N,N'-dimethyl-2-oxoethan-1 -aminium)) dichloride (CGSES12-CGSES16)

To a round-bottomed flask equipped with magnetic stirring and a condenser was added (0.021 mol) $\mathrm{N}$-(2-(dimethylamino) ethyl) dodecanamide; $N$-(2-(dimethylamino) ethyl) tetradecanamide or N-(2-(dimethylamino) ethyl) hexadecanamide and Ethane-1,2-diyl bis(2-chloroethanoate (2.14 g, $0.01 \mathrm{~mol})$. Ethyl acetate was then added. The solution was heated to the reflux and the reaction was performed for $24 \mathrm{~h}$. The obtained product was recrystallized from mixtures of ethyl acetate and ethanol $(5: 1 \mathrm{v} / \mathrm{v})$. The finished product was vacuum-dried [26,27].

\subsection{Specimens}

The chemical compositions of the MS samples ( $\mathrm{wt} \%$ ) are as follows: $0.19 \% \mathrm{C}, 0.014 \% \mathrm{Ni}, 0.003 \%$ $\mathrm{Ti}, 0.009 \% \mathrm{Cr}, 0.022 \% \mathrm{Cu}, 0.016 \% \mathrm{~V}, 0.05 \% \mathrm{Si}, 0.009 \% \mathrm{P}, 0.94 \% \mathrm{Mn}, 0.004 \% \mathrm{~S}, 0.034 \% \mathrm{Al}$; the rest is $\mathrm{Fe}$, as determined using an ARL ${ }^{\mathrm{TM}} 4460$ Optical Emission 8 Spectrometer (Waltham, Middlesex, Massachusetts, USA). MS samples were abraded with emery papers with dissimilar grades (600-1200), and cleaned with acetone and distilled water.

\subsection{Electrochemical Techniques}

The electrochemical curves were determined using an OrigaLys device (OrigaLys ElectroChem SAS, 69140 Rillieux-la-Pape, Lyon, France), and analyzed in the OrigaMaster 5 software (OrigaLys ElectroChem SAS, 69140 Rillieux-la-Pape, Lyon France). An electrochemical cell contains a working electrode (WE), a saturated calomel electrode (SCE) as a reference electrode, and a platinum counter electrode (CE). The WE used in this study was MS fixed in a PVC vessel using epoxy resin; the uncovered area of the electrode in the solution was $0.34 \mathrm{~cm}^{2}$. First, the WE was submerged in a testing solution with an open circuit potential (OCP) for $30 \mathrm{~min}$, until a stable state was attained. Potentiodynamic polarization (PP) measurements were implemented in a potential range from -800 to $-300 \mathrm{mV}$ vs. SCE at OCP with a scan rate of $0.2 \mathrm{mV} \mathrm{s}^{-1}$ at $20^{\circ} \mathrm{C}$. Electrochemical impedance spectroscopy (EIS) measurements were made in the frequency range of $100 \mathrm{kHz}-30 \mathrm{mHz}$ at a small alternating voltage perturbation $(10 \mathrm{mV})$ at $20^{\circ} \mathrm{C}$.

\subsection{Gravimetric Measurements}

MS samples $(2 \mathrm{~cm} \times 6 \mathrm{~cm} \times 0.6 \mathrm{~cm})$ were soaked in $1 \mathrm{M} \mathrm{HCl}$ solution for one day in the absence and presence of numerous concentrations of CGSES12, CGSES14 and CGSES16. Then, the weight losses were measured and reported.

\subsection{Surface Tension Measurements}

A surface tension test was carried out as previously described [28-30]. The procedure is described in detail in the Supplementary Materials. 


\section{Results and Discussion}

A series of three cationic gemini surfactants with ester spacer (CGSES12-16) was produced by acylation of the primary amino group $N, N$-dimethyl ethylenediamine with fatty acyl chloride using anhydrous diethyl ether as a solvent (Scheme 1). The corresponding N-(2 (dimethylamino)ethyl) alkanamide (DAEA12-16) intermediates were stirred independently with Ethane-1,2-diyl bis(2-chloroethanoate) (ES) to produce the desired surfactants after $24 \mathrm{~h}$.

\subsection{Construction Explanation}

All synthesized cationic surfactants structures (CGSES12-16) were established using MS, NMR and FTIR, and the corresponding intermediates.

The FTIR spectra of the intermediates (DAEA12-16) showed a strong absorption band at $1634-1643 \mathrm{~cm}^{-1}$, which is characteristic for $\mathrm{C}=\mathrm{O}$ amide, and a sharp band in the range of $3291-3298 \mathrm{~cm}^{-1}$ for $\mathrm{NH}$ stretching. In addition to the distinct intermediate peaks (DAEA12-16), there was a strong peak at $1740-1755 \mathrm{~cm}^{-1}$ which corresponds to the absorption of $\mathrm{C}=\mathrm{O}$ of the ester group for CGSES12-16 (Table 1, Figure 1).

Table 1. FT-IR data of cationic gemini surfactant.

\begin{tabular}{cccccc}
\hline \multirow{2}{*}{$\begin{array}{c}\text { Cationic Gemini } \\
\text { Surfactants }\end{array}$} & \multirow{2}{*}{$\mathbf{~ N - H )}$} & $\begin{array}{c}\boldsymbol{v} \text { C-H } \\
\text { Asym. }\end{array}$ & $\begin{array}{c}\boldsymbol{v} \text { C-H } \\
\text { Sym }\end{array}$ & $\begin{array}{c}\boldsymbol{v} \text { C=O } \\
\text { Ester }\end{array}$ & $\begin{array}{c}\boldsymbol{v} \text { C=O } \\
\text { Amide }\end{array}$ \\
\cline { 2 - 6 } & 3329 & 2925 & 2842 & 1740 & 1641 \\
CGSES12 & 3324 & 2919 & 2842 & 1747 & 1641 \\
CGESE14 & 3352 & 2911 & 2850 & 1755 & 1648 \\
\hline CGSES16 &
\end{tabular}

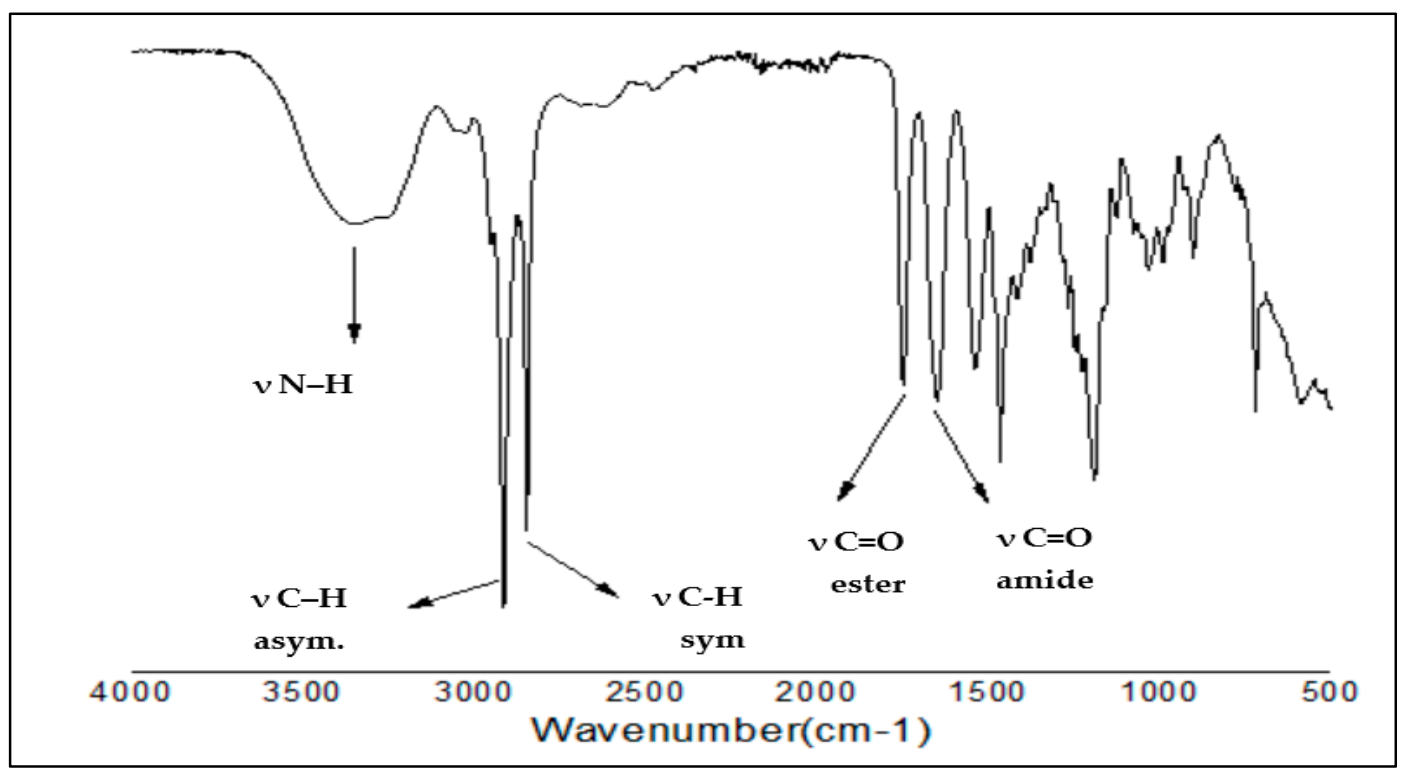

Figure 1. FT-IR spectrum for CGSES14.

The structure of CGSES14 is given as an example here. Providing the ${ }^{1} \mathrm{H}$ NMR data for CGSES14 (Table 2, Figure 2), chemical shifts for methyl and methylene protons $\mathrm{CH}_{2}$ of the hydrophobic tail of the cationic gemini surfactants occurred at 0.86 and $1.20 \mathrm{ppm}$, respectively. A methylene proton signal before the carbonyl group, which is a part of the fatty chain, was seen at $\delta 2.19 \mathrm{ppm}$. The resonance of two methyl protons directly bound to the positive charge quaternary nitrogen $\left[\mathrm{N}^{+}\left(\mathrm{CH}_{3}\right)_{2}\right]$ was detected as a singlet at $\delta 3.57 \mathrm{ppm}$. The peaks at 3.92 and $3.72 \mathrm{ppm}$ could be attributed to the methylene protons between the two nitrogen atoms, i.e., $\mathrm{N}-\mathrm{CH}_{2}-\mathrm{CH}_{2}-\mathrm{N}^{+}$. A typical resonance signal for the hydrogen 
protons of the methylene group directly bound to the positively charged quaternary nitrogen, which is a part of ester spacer, was identified from $\delta 4.49 \mathrm{ppm}$. The methylene proton signal next to the ester group, which is part of the spacer, was detected at $\delta 5.01 \mathrm{ppm}$. The resonance of one proton attached to nitrogen was shifted to the up field, and was affected by the ester group of the spacer, which was observed as a singlet at $8.45 \mathrm{ppm}$.

Table 2. ${ }^{1} \mathrm{H}$ NMR reading describing the type of proton in CGSES12-16.

\begin{tabular}{|c|c|c|c|c|c|c|c|c|c|c|}
\hline \multirow{3}{*}{$\begin{array}{c}\text { Cationic } \\
\text { Gemini } \\
\text { Surfactants }\end{array}$} & \multicolumn{10}{|c|}{ Proton NMR ( $\delta$ in ppm, $850 \mathrm{MHz}, \mathrm{CDCl}_{3}$ ) } \\
\hline & \multicolumn{4}{|c|}{ Tail } & \multirow{2}{*}{$\begin{array}{c}\text { Amide } \\
\begin{array}{c}\mathrm{NH} \\
\text { (e) }\end{array}\end{array}$} & \multicolumn{3}{|c|}{ Amido-Amine } & \multicolumn{2}{|c|}{ Spacer } \\
\hline & $\begin{array}{l}\mathrm{CH}_{3} \\
\text { (a) }\end{array}$ & $\begin{array}{c}\mathrm{CH}_{2} \\
\text { (b) }\end{array}$ & $\begin{array}{c}\mathrm{CH}_{2} \\
\text { (c) }\end{array}$ & $\begin{array}{c}\mathrm{CH}_{2} \\
\text { (d) }\end{array}$ & & $\begin{array}{c}\mathrm{CH}_{2} \\
\text { (f) }\end{array}$ & $\begin{array}{c}\mathrm{CH}_{2} \\
\text { (g) }\end{array}$ & $\begin{array}{c}\mathrm{CH}_{3} \\
\text { (h) }\end{array}$ & $\begin{array}{c}\mathrm{CH}_{2} \\
\text { (i) }\end{array}$ & $\begin{array}{c}\mathrm{CH}_{2} \\
\text { (j) }\end{array}$ \\
\hline CGSES12 & 0.83 & 1.16 & 1.51 & 2.16 & 8.42 & 3.89 & 3.74 & 3.51 & 4.45 & 5.03 \\
\hline CGESE14 & 0.86 & 1.20 & 1.55 & 2.19 & 8.45 & 3.92 & 3.72 & 3.57 & 4.49 & 5.01 \\
\hline CGSES16 & 0.86 & 1.23 & 1.58 & 2.28 & 8.48 & 3.67 & 3.57 & 3.53 & 4.48 & 5.08 \\
\hline
\end{tabular}

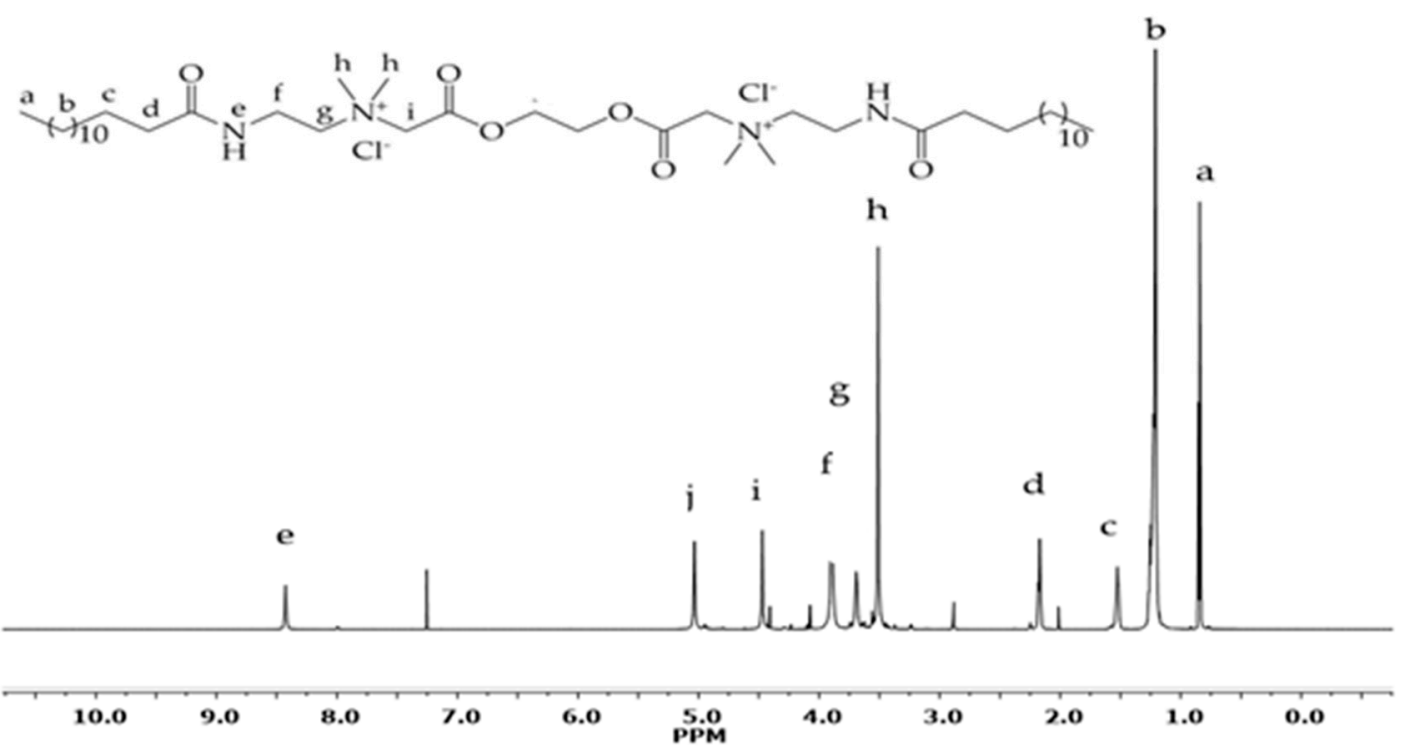

Figure 2. ${ }^{1} \mathrm{H}-\mathrm{NMR}$ spectrum CGSES14.

Also, the mass spectra data obtained for all of the studied current cationic gemini surfactants confirmed the chemical composition. The calculated molecular weight $\mathrm{m} / \mathrm{z}$ values for cationic gemini surfactants $(755.948,812.057,868.164$,$) perfectly matched the practical values (755,812,868)$ for CGSES12, CGSES14 and CGSES16 respectively (Table 3, Figure 3). The spectral data figures of the other synthesized cationic gemini surfactants with ester spacer are also provided in ESI (Figures S1-S14).

Table 3. GC-MS data of CGSES12-16.

\begin{tabular}{|c|c|c|}
\hline $\begin{array}{l}\text { Cationic Gemini } \\
\text { Surfactants }\end{array}$ & Base Peak & Proposed Structure \\
\hline CGSES12 & 502.45 & 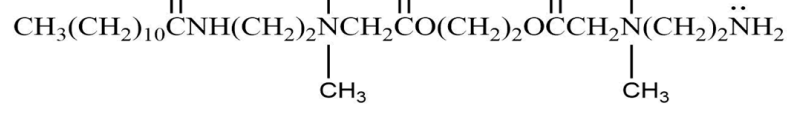 \\
\hline CGSES14 & 470.48 & $\mathrm{CH}_{3}\left(\mathrm{CH}_{2}\right)_{12} \mathrm{CNH}\left(\mathrm{CH}_{2}\right)_{2} \mathrm{NCH}_{2} \mathrm{CO}\left(\mathrm{CH}_{2}\right)_{2} \mathrm{OCCH}_{2} \mathrm{~N}+$ \\
\hline CGSES16 & 57.07 & $\mathrm{CH}_{3}\left(\mathrm{CH}_{2}\right)_{3}{ }^{+}$ \\
\hline
\end{tabular}




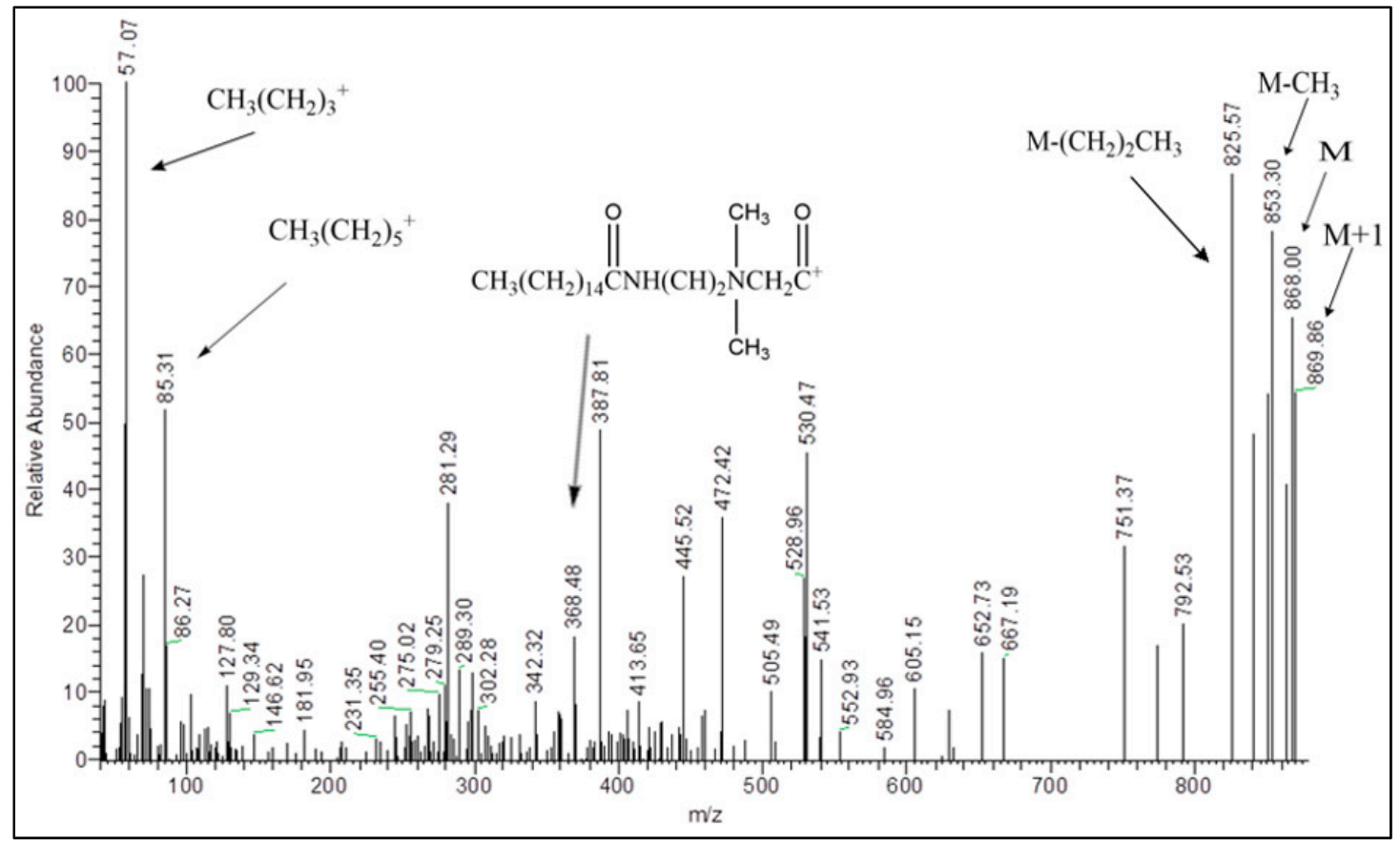

Figure 3. Mass spectrum for CGSES16.

\subsection{Potentiodynamic Polarization}

Figures 4-6 show the Tafel curves of MS in $1 \mathrm{M} \mathrm{HCl}$ in the absence and presence of dissimilar concentrations (0.0001, 0.005, 0.001 and $0.0025 \mathrm{M})$ of CGSES12, CGSES14 and CGSES16 at $20{ }^{\circ} \mathrm{C}$. The addition of CGSES12, CGSES14, or CGSES16 moved the anodic and cathodic curves to a lower current density. This indicated that the corrosive anodic and cathodic reactions of MS were significantly inhibited by CGSES12, CGSES14 or CGSES16. Also, the Tafel curves match with each other. This indicates the activated control of both cathodic hydrogen permission and anodic ferrous dissolution. The corrosion parameters, like corrosion current density $\left(i_{\text {corr }}\right)$, corrosion potential $\left(E_{\text {corr }}\right)$, anodic and cathodic Tafel slopes $\left(\beta_{\mathrm{a}}\right.$ and $\left.\beta_{\mathrm{c}}\right)$, were calculated using the OrigaMaster 5 software and are listed in Table 4 . From the data in Table 4 , it can be seen that $i_{\text {corr }}$ decreased after adding CGSES12, CGSES14 or CGSES16 to $1 \mathrm{M} \mathrm{HCl}$; it decreased gradually with greater CGSES12, CGSES14 or CGSES16 concentrations. This indicates that CGSES12, CGSES14 and CGSES16 are effective corrosion inhibitors. The corrosion inhibition efficiency (IE) was calculated as follows [31,32]:

$$
I E=\frac{i_{\text {corr }}-i_{\text {corr }}(\mathrm{inh})}{i_{\text {corr }}} \times 100
$$

where the corrosion current densities for MS in the uninhibited and inhibited solutions are represented by $i_{\text {corr }}$ and $i_{\text {corr }}($ inh), respectively.

The best inhibition efficiencies were 92.14, 95.77 and $96.40 \%$ for CGSES12, CGSES14 and CGSES16, respectively. This indicates that the inhibition efficiency increases with increasing the hydrophobic part (fatty alkyl chain) of the tested compounds.

$E_{\text {corr }}$ is slightly changed in the presence of CGSES12, CGSES14 and CGSES16 for $1 \mathrm{M} \mathrm{HCl}$, indicating that CGSES12, CGSES14 and CGSES16 are mixed-type inhibitors. Moreover, the electrochemical mechanisms of CGSES12, CGSES14 and CGSES16 may be attributed to the blocking effect [33]. The Tafel slopes $\left(\beta_{\mathrm{a}}\right.$ and $\left.\beta_{\mathrm{c}}\right)$ changed slightly after the addition of CGSES12, CGSES14 and CGSES16 to a blank solution, indicating that CGSES12, CGSES14 and CGSES16 block the anodic and cathodic sites of the MS surface without affecting the dissolution reaction mechanism. 


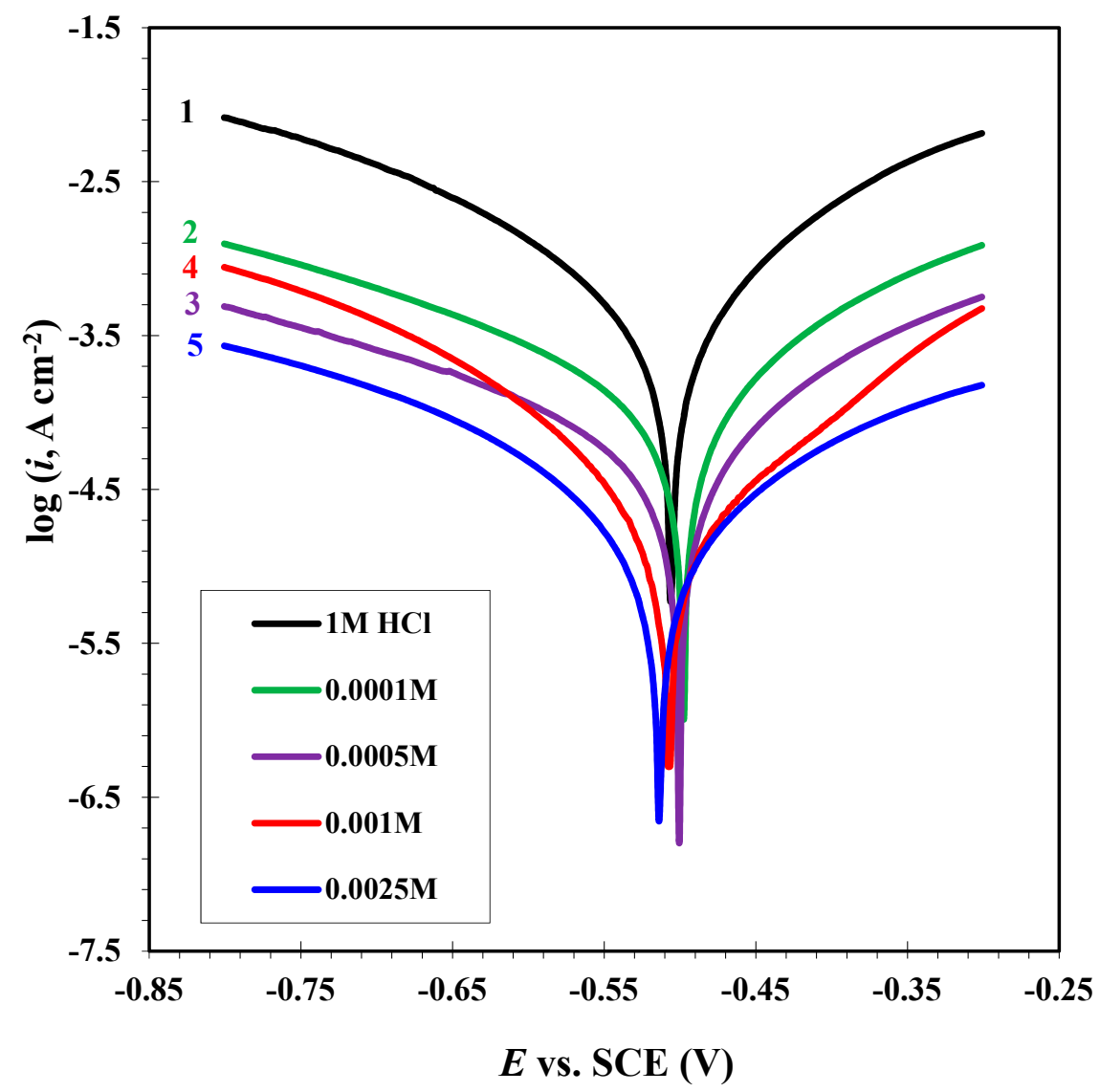

Figure 4. Anodic and cathodic polarization curves for MS obtained at $20{ }^{\circ} \mathrm{C}$ in $1 \mathrm{M} \mathrm{HCl}$ solution in the absence and presence of different concentrations of CGSES12.

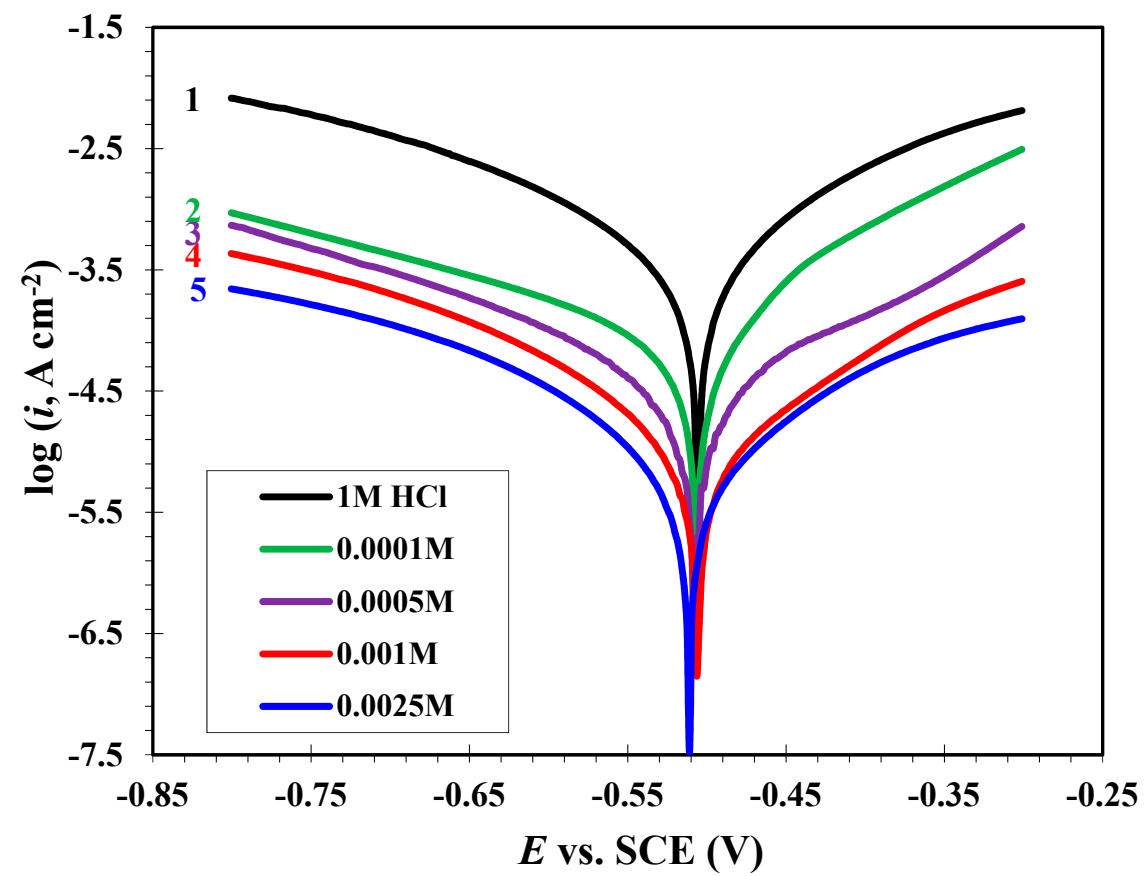

Figure 5. Anodic and cathodic polarization curves for MS obtained at $20^{\circ} \mathrm{C}$ in $1 \mathrm{M} \mathrm{HCl}$ solution in the absence and presence of different concentrations of CGSES14. 


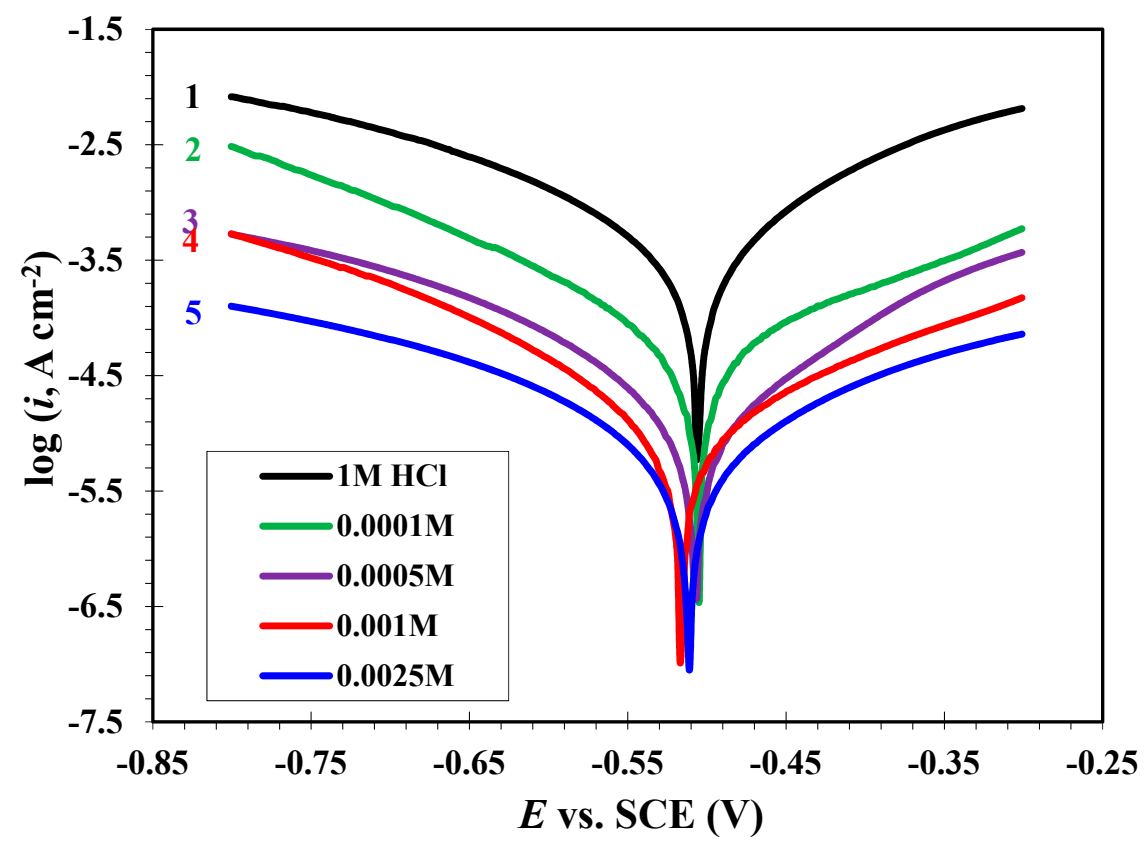

Figure 6. Anodic and cathodic polarization curves for MS obtained at $20^{\circ} \mathrm{C}$ in $1 \mathrm{M} \mathrm{HCl}$ solution in the absence and presence of different concentrations of CGSES16.

Table 4. Potentiodynamic polarization parameters for $\mathrm{CS}$ in $1 \mathrm{M} \mathrm{HCl}$ with and without different concentrations of the synthesized cationic gemini surfactants at $20^{\circ} \mathrm{C}$.

\begin{tabular}{ccccccc}
\hline $\begin{array}{c}\text { Inhibitor } \\
\text { Name }\end{array}$ & $\begin{array}{c}\text { Conc. of } \\
\text { Inhibitor } \\
(\mathbf{M})\end{array}$ & $\begin{array}{c}\boldsymbol{E}_{\text {corr }} \\
(\mathbf{m V} \text { vs. SCE) }\end{array}$ & $\begin{array}{c}\boldsymbol{i}_{\text {corr }} \\
\left(\mathbf{m A ~ c m}^{-2}\right)\end{array}$ & $\begin{array}{c}\boldsymbol{\beta}_{\mathbf{a}} \\
\left(\mathbf{m V ~ d e c}^{-1}\right)\end{array}$ & $\begin{array}{c}\boldsymbol{\beta}_{\mathbf{c}} \\
\left(\mathbf{m V ~ d e c}^{-1}\right)\end{array}$ & $\begin{array}{c}I E \\
(\mathbf{\%})\end{array}$ \\
\hline- & 0.00 & -508.4 & 0.4134 & 135.8 & -162.5 & - \\
& $1.0 \times 10^{-4}$ & -510.9 & 0.1041 & 160.0 & -181.3 & 74.82 \\
CGSES12 & $5.0 \times 10^{-4}$ & -513.5 & 0.0665 & 162.5 & -183.3 & 83.91 \\
& $1.0 \times 10^{-3}$ & -514.8 & 0.0481 & 125.4 & -147.1 & 88.36 \\
& $2.5 \times 10^{-3}$ & -516.1 & 0.0325 & 165.9 & -187.3 & 92.14 \\
\hline & $1.0 \times 10^{-4}$ & -509.8 & 0.0877 & 114.6 & -192.9 & 78.79 \\
CGSES14 & $5.0 \times 10^{-4}$ & -510.5 & 0.0467 & 161.8 & -174.6 & 88.70 \\
& $1.0 \times 10^{-3}$ & -508.3 & 0.0281 & 163.4 & -177.1 & 93.20 \\
& $2.5 \times 10^{-3}$ & -513.2 & 0.0175 & 182.5 & -178.3 & 95.77 \\
\hline & $1.0 \times 10^{-4}$ & -507.8 & 0.0677 & 171.7 & -157.8 & 83.62 \\
CGSES16 & $5.0 \times 10^{-4}$ & -509.5 & 0.0356 & 155.9 & -190.1 & 91.39 \\
& $1.0 \times 10^{-3}$ & -517.8 & 0.0196 & 184.2 & -182.0 & 95.26 \\
& $2.5 \times 10^{-3}$ & -513.8 & 0.0149 & 185.5 & -195.3 & 96.40 \\
\hline
\end{tabular}

\subsection{EIS Results}

The Nyquist spectra of MS in $1 \mathrm{M} \mathrm{HCl}$ without and with of different concentrations $(0.0001,0.0005$, 0.001 and $0.0025 \mathrm{M}$ ) of CGSES12, CGSES14 and CGSES16 are shown in Figures 7-9. The diameter of the capacitive loop was higher in the presence CGSES12, CGSES14 and CGSES16. In addition, the diameter of the semicircle for the charge transfer resistance $\left(R_{\mathrm{ct}}\right)$ increased with an increase in the concentrations of CGSES12, CGSES14 and CGSES16 from $0.0001 \mathrm{M}$ to $0.0025 \mathrm{M}$. This indicates that these compounds adsorbed on the MS surface by blocking the active sites [34]. These spectra exhibited one single loop, indicating that the $\mathrm{MS}$ corrosion in $1 \mathrm{M} \mathrm{HCl}$ was controlled by the charge transfer process [35]. 


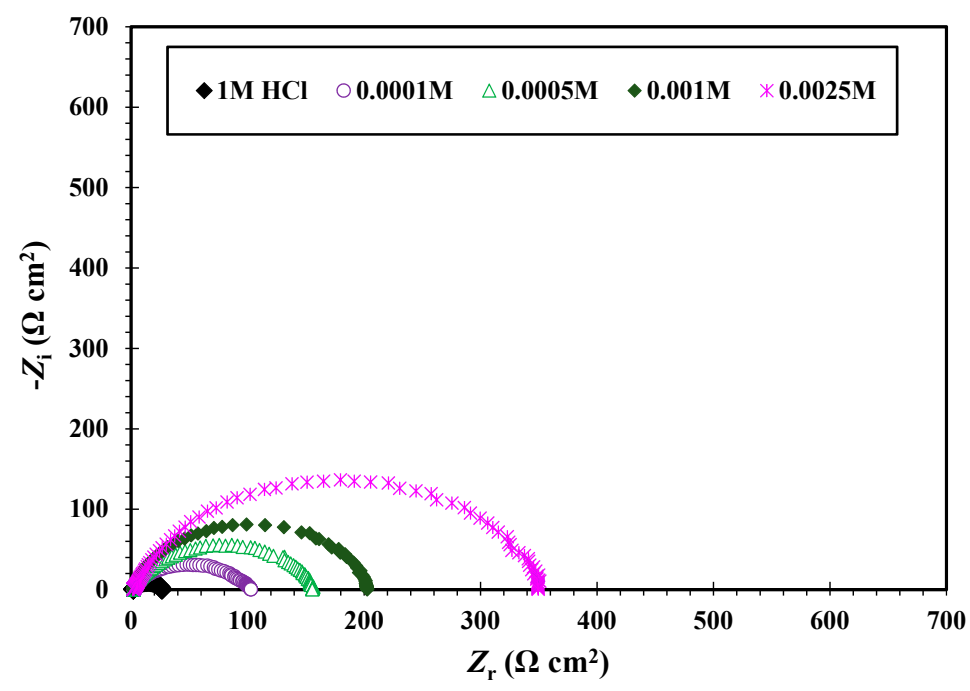

Figure 7. Nyquist plots for $\mathrm{MS}$ in $1 \mathrm{M} \mathrm{HCl}$ in the absence and presence of different concentrations of CGSES12 at $20^{\circ} \mathrm{C}$.

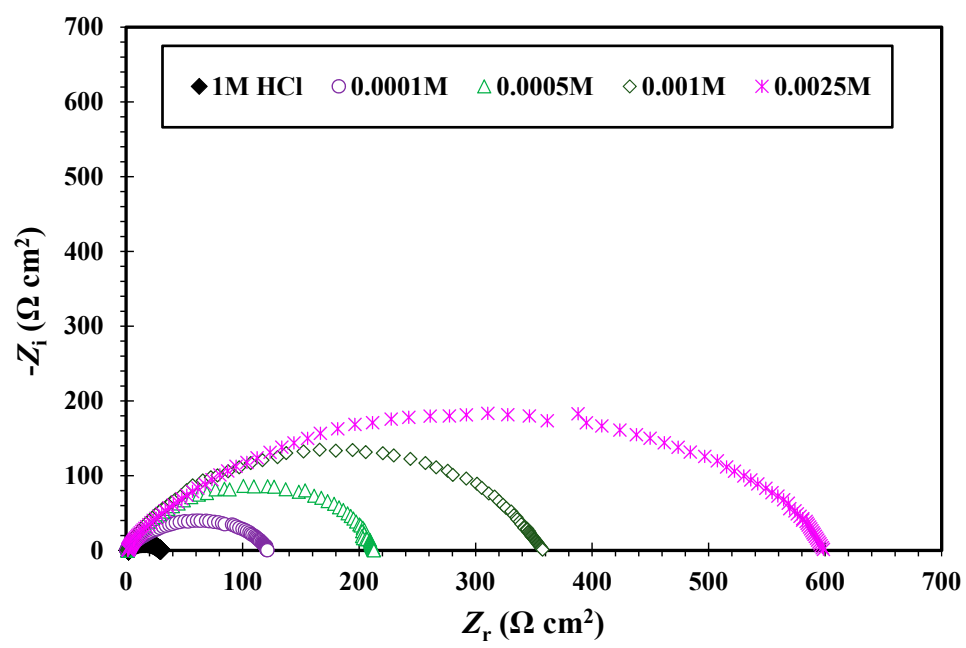

Figure 8. Nyquist plots for $\mathrm{MS}$ in $1 \mathrm{M} \mathrm{HCl}$ in the absence and presence of different concentrations of CGSES14 at $20^{\circ} \mathrm{C}$.

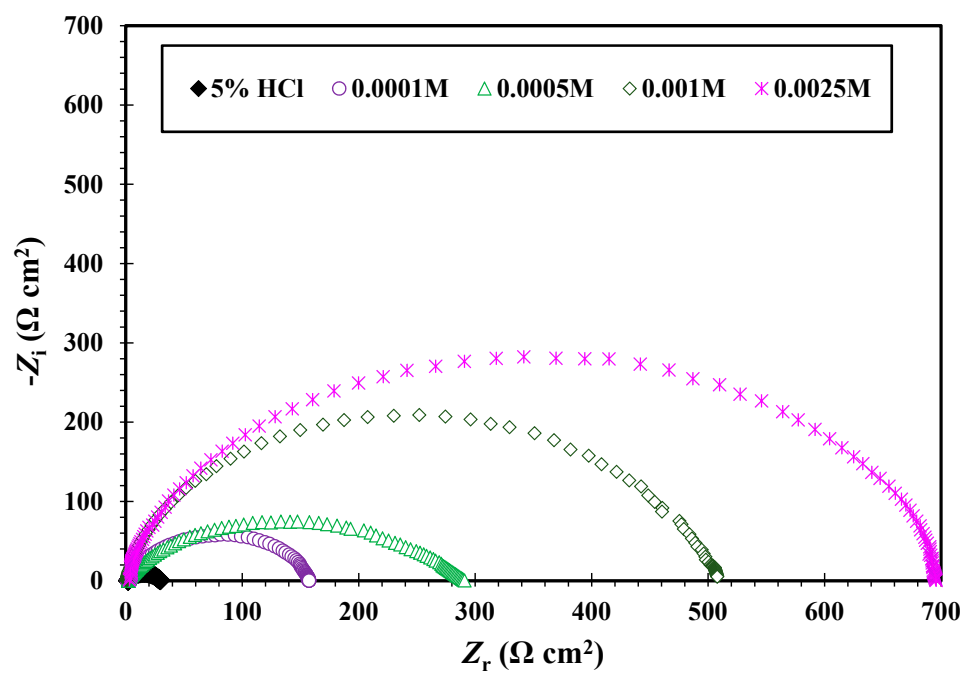

Figure 9. Nyquist plots for $\mathrm{MS}$ in $1 \mathrm{M} \mathrm{HCl}$ in the absence and presence of different concentrations of CGSES16 at $20^{\circ} \mathrm{C}$. 
Figures 10-12 show the Bode and Phase angle plots for MS without and with CGSES12, CGSES14 and CGSES16 in $1 \mathrm{M} \mathrm{HCl}$. From these figures, we can see that the impedance value of the MS electrode in the bank solution was reduced in the presence of CGSES12, CGSES14 and CGSES16. The absolute impedance increased with increasing the concentration of CGSES12, CGSES14 and CGSES16. This means that CGSES12, CGSES14 and CGSES16 slow the ferrous dissolution and $\mathrm{H}_{2}$ evolution processes at the MS surface. Figures 10-12 show a one phase peak which indicates that an one time constant related to the capacitive loop was present. We noted that the Nyquist and Bode shapes were the same after adding various concentrations of CGSES12, CGSES14 and CGSES16. This means that the mechanism of MS dissolution and hydrogen gas evolution in $1 \mathrm{M} \mathrm{HCl}$ was unmodified after adding CGSES12, CGSES14 and CGSES16. Also, the Nyquist plots were not perfect semicircles, and the phase angles were below $90^{\circ}$. This was the result of the roughness and inhomogeneity of the MS surface. This behavior was due to the frequency dispersion at a low frequency, leading to the deviation from an ideal electrical capacitance of the double layer $\left(C_{\mathrm{dl}}\right)$ [36-38]. In this case, the constant phase element $(C P E)$ is used instead of $C_{\mathrm{dl}}$, because $C P E$ is more accurate $[39,40]$.

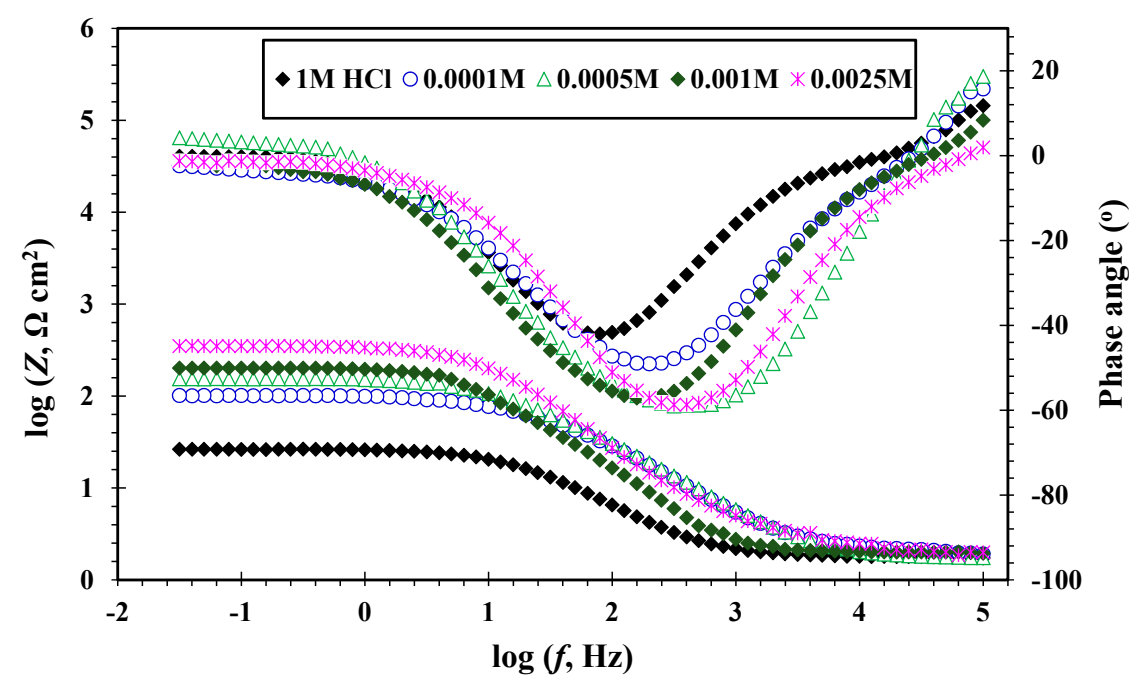

Figure 10. Bode plots for $\mathrm{MS}$ in $1 \mathrm{M} \mathrm{HCl}$ in the absence and presence of different concentrations of CGSES12 at 20.

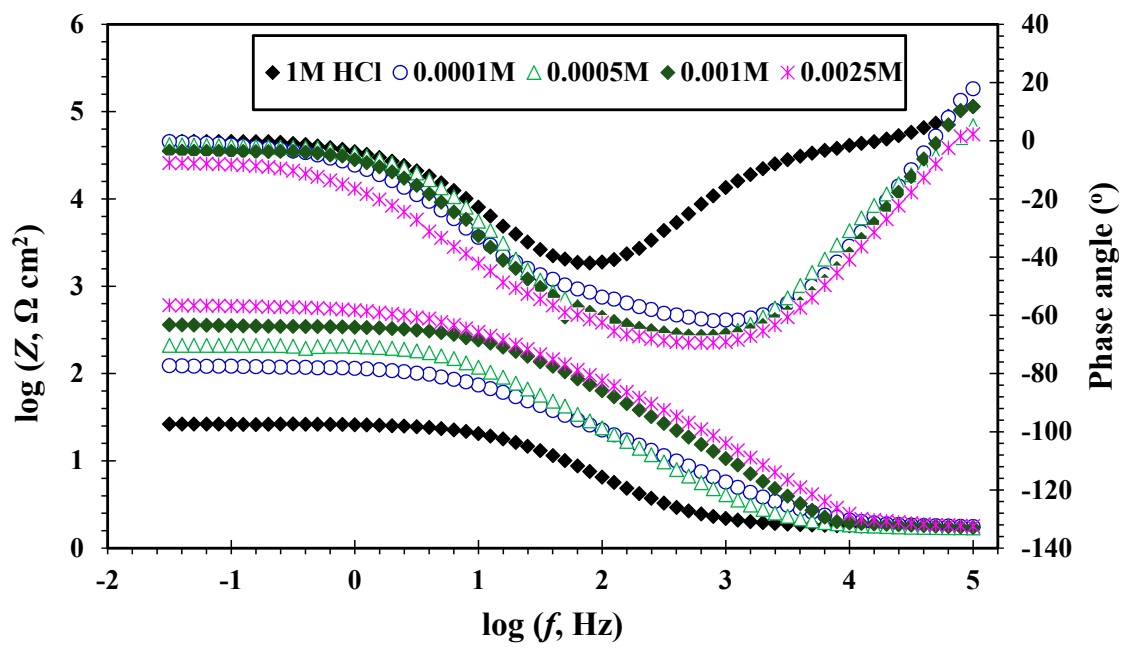

Figure 11. Bode plots for $\mathrm{MS}$ in $1 \mathrm{M} \mathrm{HCl}$ in the absence and presence of different concentrations of CGSES14 at $20^{\circ} \mathrm{C}$. 


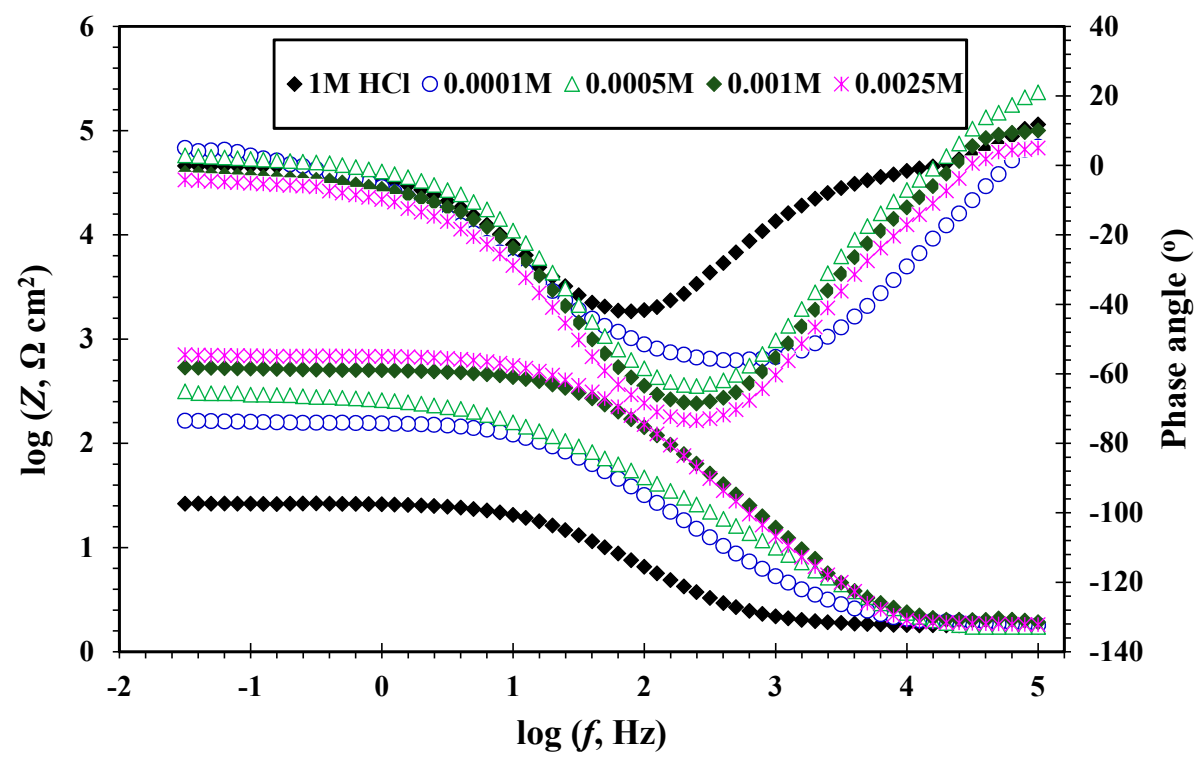

Figure 12. Bode plots for $\mathrm{MS}$ in $1 \mathrm{M} \mathrm{HCl}$ in the absence and presence of different concentrations of CGSES16 at $20^{\circ} \mathrm{C}$.

EIS data were simulated using the same circuit as that shown in Figure 13. A simulation of the EIS and Bode plots made using the ZSimpWin software is shown in Figures 14 and 15. It was observed that the values of Chsq (i.e., a measure of the confidence degree regarding the simulations) ranged from 0.00193 to 0.00893 . This indicated the correctness of the proposed equivalent circuit. CPE consists of $Q_{\mathrm{dl}}$ and $n$ (dispersion coefficient), where $n$ determines the inhomogeneous degree of the MS/solution interface resulting from surface roughness, inhibitor adsorption, porous layer formation, etc. $C_{\mathrm{dl}}$ and absolute impedance $\left(Z_{\mathrm{CPE}}\right)$ can be calculated from the following equation using CPE [41,42]:

$$
\begin{aligned}
C_{\mathrm{dl}} & =Q_{\mathrm{dl}}\left(\omega_{\max }\right)^{\mathrm{n}-1} \\
Z_{\mathrm{CPE}} & =Q_{\mathrm{dl}}{ }^{-1}\left(i \omega_{\max }\right)^{-\mathrm{n}}
\end{aligned}
$$

where $\omega=2 \pi f_{\max }, f_{\max }$ is the frequency at the maxim um imaginary element of the impedance.

The inhibition efficiency $(I E)$ was calculated using the following equation $[43,44]$ :

$$
I E=\frac{R_{\mathrm{ct}}^{\circ}-R_{\mathrm{ct}}}{R_{\mathrm{ct}}^{\circ}} \times 100
$$

where $R_{\text {ct }}^{\circ}$ and $R_{\mathrm{ct}}$ are the charge-transfer resistance with and without the inhibitor.

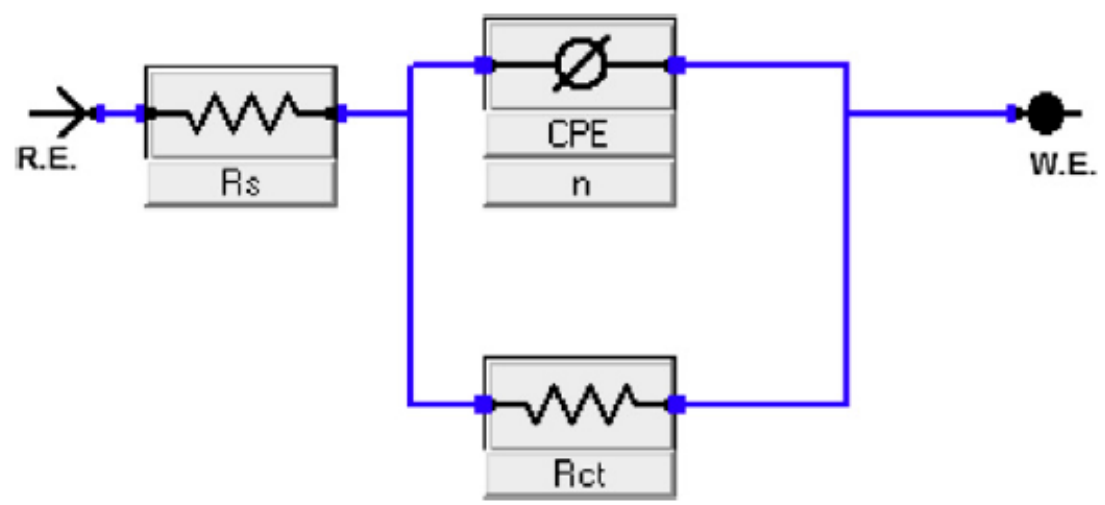

Figure 13. The suggested equivalent circuit model for the studied system. 

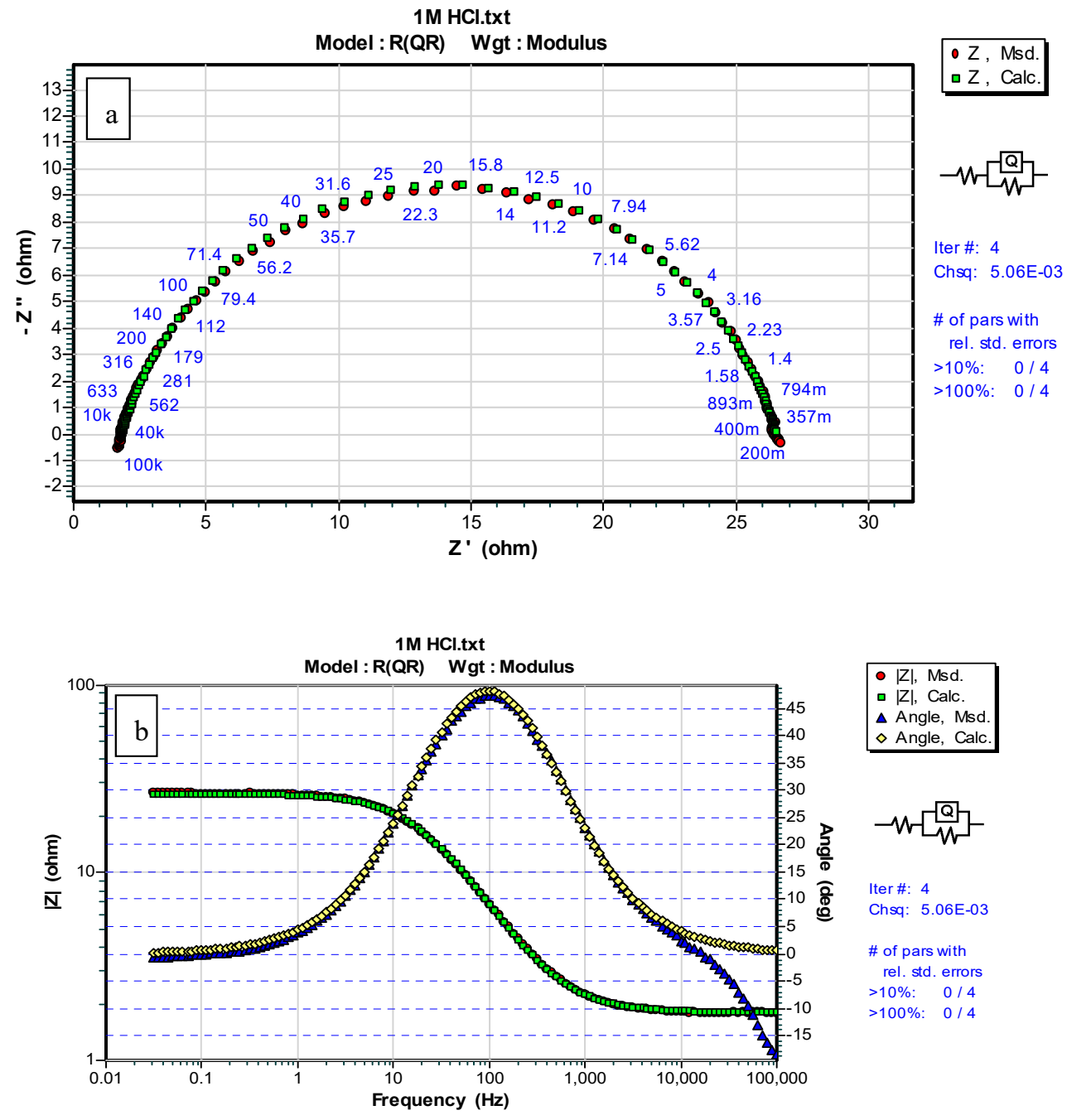

Figure 14. Simulation of EIS (a) and Bode (b) plots for MS in $1 \mathrm{M} \mathrm{HCl}$ at $20^{\circ} \mathrm{C}$.

The electrochemical data are summarized in Table 5. It was noted that $R_{\mathrm{ct}}$ and $\eta_{\mathrm{I}}$ increased with increasing concentrations of CGSES12, CGSES14 and CGSES16. $R_{\mathrm{ct}}$ was reached at the maximum concentration $(0.0025 \mathrm{M})$, confirming that the inhibitor prevents the charge transfer of the dissolution and $\mathrm{H}_{2}$ evolution processes. $R_{\mathrm{ct}}$ was associated with a slower corroding system. $R_{\mathrm{ct}}$ and $\eta_{\mathrm{I}}$ were reached at the maximum concentration $(0.0025 \mathrm{M})$. The $R_{\mathrm{ct}}$ and $I E$ of these materials follow the order:

\section{CGSES16 > CGSES14 > CGSES12}

This indicates that the inhibition efficiency increased with increasing the hydrophobic part (fatty alkyl chain) of the tested inhibitors.

The dispersion coefficients $(n)$ for CGSES12, CGSES14 and CGSES16 were in the range of 0.75 to 0.98 . This means that the MS surface was inhomogeneous, but not the plane. Therefore ideal capacitance $\left(C_{\mathrm{dl}}\right)$ must be replaced nonideal capacitance (CPE). From Table 2, we noted that $C_{\mathrm{dl}}$ for the inhibited solution was higher than for the uninhibited solution. The decrease in $C_{\mathrm{dl}}$ with increasing the inhibitor concentration was due to the increase in thickness or decrease in the dielectric constant of the adsorption film. This confirmed the adsorption of CGSES12, CGSES14 and CGSES16 molecules on the MS surface, instead of water molecules $[45,46]$. 

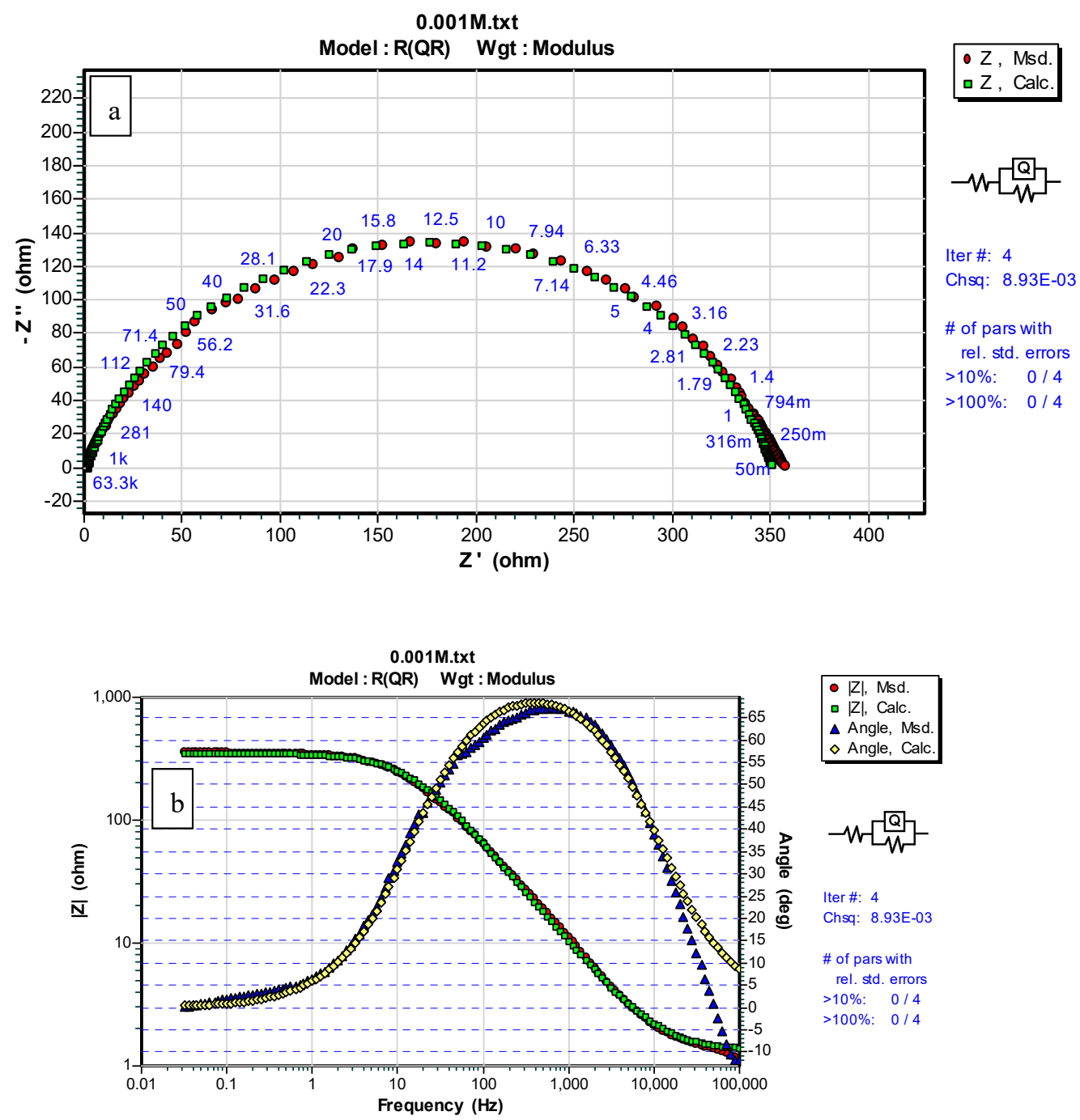

Figure 15. Simulation of EIS (a) and Bode (b) plots for MS in $1 \mathrm{M} \mathrm{HCl}$ in the presence of $0.001 \mathrm{M}$ of CGSES14 at $20^{\circ} \mathrm{C}$.

Table 5. Electrochemical impedance parameters for $\mathrm{CS}$ in $1 \mathrm{M} \mathrm{HCl}$ with and without different concentrations of the synthesized cationic gemini surfactants at $20{ }^{\circ} \mathrm{C}$.

\begin{tabular}{|c|c|c|c|c|c|c|c|c|}
\hline $\begin{array}{l}\text { Inhibitor } \\
\text { Name }\end{array}$ & $\begin{array}{l}\text { Conc. of Inhibitor } \\
\text { (M) }\end{array}$ & $\begin{array}{c}R_{\mathrm{s}} \\
\left(\Omega \mathrm{cm}^{2}\right)\end{array}$ & $\begin{array}{c}Q_{\mathrm{dl}} \\
\left(\mathrm{m} \Omega^{-1} \mathrm{~s}^{\mathrm{n}} \mathrm{cm}^{-2}\right)\end{array}$ & $n$ & $\begin{array}{c}R_{\mathrm{ct}} \\
\left(\Omega \mathrm{cm}^{2}\right)\end{array}$ & Chsq & $\begin{array}{c}C_{\mathrm{dl}} \\
\left(\mu \mathrm{F} \mathrm{cm}^{-2}\right)\end{array}$ & $\begin{array}{l}I E \\
(\%)\end{array}$ \\
\hline \multirow[t]{2}{*}{ - } & 0.00 & 1.80 & 0.7691 & 0.83 & 24.73 & 0.00506 & 97.8 & - \\
\hline & $1.0 \times 10^{-4}$ & 2.39 & 0.2192 & 0.82 & 96.45 & 0.00427 & 28.3 & 74.36 \\
\hline \multirow{4}{*}{ CGSES12 } & $5.0 \times 10^{-4}$ & 1.75 & 0.1385 & 0.82 & 152.8 & 0.00654 & 18.6 & 83.82 \\
\hline & $1.0 \times 10^{-3}$ & 1.78 & 0.1097 & 0.92 & 199.6 & 0.00665 & 14.3 & 87.61 \\
\hline & $2.5 \times 10^{-3}$ & 1.92 & 0.0674 & 0.79 & 362.8 & 0.00848 & 8.1 & 93.18 \\
\hline & $1.0 \times 10^{-4}$ & 1.50 & 0.1848 & 0.75 & 120.7 & 0.00426 & 24.5 & 79.51 \\
\hline \multirow{3}{*}{ CGSES14 } & $5.0 \times 10^{-4}$ & 1.30 & 0.1032 & 0.87 & 211.0 & 0.00764 & 13.8 & 88.28 \\
\hline & $1.0 \times 10^{-3}$ & 1.33 & 0.0637 & 0.83 & 349.8 & 0.00893 & 9.3 & 92.93 \\
\hline & $2.5 \times 10^{-3}$ & 1.64 & 0.0364 & 0.77 & 573.5 & 0.00281 & 5.1 & 95.69 \\
\hline \multirow{4}{*}{ CGSES16 } & $1.0 \times 10^{-4}$ & 1.44 & 0.1377 & 0.75 & 162.4 & 0.00785 & 17.8 & 84.77 \\
\hline & $5.0 \times 10^{-4}$ & 1.93 & 0.0792 & 0.74 & 280.5 & 0.00704 & 9.9 & 91.18 \\
\hline & $1.0 \times 10^{-3}$ & 1.79 & 0.0411 & 0.96 & 502.9 & 0.00237 & 5.7 & 95.08 \\
\hline & $2.5 \times 10^{-3}$ & 1.66 & 0.0327 & 0.88 & 671.1 & 0.00193 & 4.2 & 96.32 \\
\hline
\end{tabular}




\subsection{Weight Loss}

The corrosion rate $(k)$ and inhibition efficiency $(I E)$ were calculated using the following equations $[47,48]$ :

$$
\begin{gathered}
k=\frac{\Delta \mathrm{W}}{A t} \\
I E=\frac{\left(k_{\text {free }}-k_{\text {inh }}\right)}{k_{\text {free }}} \times 100
\end{gathered}
$$

where $\Delta \mathrm{W}$ is the average $\mathrm{WL}, A$ is the surface area $\left(\mathrm{cm}^{2}\right), t$ is the time $(\mathrm{h}), k_{\text {free }}$ and $k_{\text {inh }}$ the corrosion rates of MS in the blank without and with unlike concentrations of inhibitor, respectively. $k$ and $I E$ of MS were determined in the presence and absence of CGSES12, CGSES14 and CGSES16 in $1 \mathrm{M} \mathrm{HCl}$ at dissimilar concentrations and temperatures; see Table 6. 
Table 6. Weight loss results for $\mathrm{MS}$ in $1 \mathrm{M} \mathrm{HCl}$ in the absence and presence of different concentrations of the synthesized cationic gemini surfactants at various temperatures.

\begin{tabular}{|c|c|c|c|c|c|c|c|c|c|c|c|c|c|}
\hline \multirow{2}{*}{$\begin{array}{l}\text { Inhibitor } \\
\text { Name }\end{array}$} & \multirow{2}{*}{$\begin{array}{l}\text { Inhibitor conc. } \\
\text { (M) }\end{array}$} & \multicolumn{3}{|c|}{$20^{\circ} \mathrm{C}$} & \multicolumn{3}{|c|}{$40^{\circ} \mathrm{C}$} & \multicolumn{3}{|c|}{$60^{\circ} \mathrm{C}$} & \multicolumn{3}{|c|}{$80^{\circ} \mathrm{C}$} \\
\hline & & $\begin{array}{c}k \\
\left(\mathrm{mg} \mathrm{cm}^{-2} \mathrm{~h}^{-1}\right)\end{array}$ & $\Theta$ & $\begin{array}{l}I E \\
(\%)\end{array}$ & $\begin{array}{c}k \\
\left(\mathrm{mg} \mathrm{cm}^{-2} \mathrm{~h}^{-1}\right)\end{array}$ & $\Theta$ & $\begin{array}{l}I E \\
(\%)\end{array}$ & $\begin{array}{c}k \\
\left(\mathrm{mg} \mathrm{cm}^{-2} \mathrm{~h}^{-1}\right)\end{array}$ & $\Theta$ & $\begin{array}{l}I E \\
(\%)\end{array}$ & $\begin{array}{c}k \\
\left(\mathrm{mg} \mathrm{cm}^{-2} \mathrm{~h}^{-1}\right)\end{array}$ & $\Theta$ & $\begin{array}{l}I E \\
(\%)\end{array}$ \\
\hline Absence & $1 \mathrm{M} \mathrm{HCl}$ & 0.3954 & - & - & 1.0712 & - & - & 2.5040 & - & - & 5.1868 & - & - \\
\hline \multirow{4}{*}{ CGSES12 } & $1.0 \times 10^{-4}$ & 0.0960 & 0.76 & 75.73 & 0.3318 & 0.69 & 69.03 & 0.9095 & 0.64 & 63.68 & 2.4744 & 0.52 & 52.29 \\
\hline & $5.0 \times 10^{-4}$ & 0.0643 & 0.84 & 83.73 & 0.2269 & 0.79 & 78.81 & 0.7539 & 0.70 & 69.89 & 1.8189 & 0.65 & 64.93 \\
\hline & $1.0 \times 10^{-3}$ & 0.0469 & 0.88 & 88.14 & 0.1418 & 0.87 & 86.76 & 0.5465 & 0.78 & 78.17 & 1.3691 & 0.74 & 73.60 \\
\hline & $2.5 \times 10^{-3}$ & 0.0240 & 0.94 & 93.93 & 0.0983 & 0.91 & 90.82 & 0.3709 & 0.85 & 85.19 & 0.9605 & 0.81 & 81.48 \\
\hline \multirow{4}{*}{ CGSES14 } & $1.0 \times 10^{-4}$ & 0.0825 & 0.79 & 79.14 & 0.8164 & 0.67 & 67.40 & 0.8164 & 0.67 & 67.40 & 2.0565 & 0.60 & 60.35 \\
\hline & $5.0 \times 10^{-4}$ & 0.0429 & 0.89 & 89.14 & 0.2806 & 0.74 & 73.81 & 0.4985 & 0.80 & 80.09 & 1.2630 & 0.76 & 75.65 \\
\hline & $1.0 \times 10^{-3}$ & 0.0266 & 0.93 & 93.27 & 0.1606 & 0.85 & 85.01 & 0.3392 & 0.86 & 86.45 & 0.9983 & 0.81 & 80.75 \\
\hline & $2.5 \times 10^{-3}$ & 0.0144 & 0.96 & 96.36 & 0.1053 & 0.90 & 90.17 & 0.2444 & 0.90 & 90.24 & 0.6530 & 0.87 & 87.41 \\
\hline \multirow{4}{*}{ CGSES16 } & $1.0 \times 10^{-4}$ & 0.0597 & 0.85 & 84.90 & 0.2398 & 0.78 & 77.62 & 0.7063 & 0.72 & 71.79 & 2.0154 & 0.64 & 64.38 \\
\hline & $5.0 \times 10^{-4}$ & 0.0314 & 0.92 & 92.05 & 0.1327 & 0.88 & 87.61 & 0.4231 & 0.83 & 83.10 & 1.2015 & 0.79 & 78.77 \\
\hline & $1.0 \times 10^{-3}$ & 0.0186 & 0.95 & 95.29 & 0.0874 & 0.92 & 91.84 & 0.3054 & 0.88 & 87.80 & 0.9931 & 0.82 & 82.45 \\
\hline & $2.5 \times 10^{-3}$ & 0.0100 & 0.97 & 97.46 & 0.0591 & 0.94 & 94.48 & 0.2133 & 0.91 & 91.48 & 0.6388 & 0.89 & 88.71 \\
\hline
\end{tabular}




\subsubsection{The Effect of Concentration}

From Table 6 , it can be seen that $k$ decreased while IE increased with increasing the concentrations of CGSES12, CGSES14 and CGSES16 from $0.0001 \mathrm{M}$ to $0.0025 \mathrm{M}$. This was illustrated by the adsorption mode of CGSES12, CGSES14 and CGSES16 covering the MS surface. At the maximum concentration $(0.0025 \mathrm{M})$, the $I E$ values were $93.93,96.36$ and $97.46 \%$ for CGSES12, CGSES14 and CGSES16, respectively, at $20^{\circ} \mathrm{C}$. Thus, these compounds were shown to be effective inhibitors for MS in $1 \mathrm{M} \mathrm{HCl}$. The efficiency of these inhibitors follows the order:

\section{CGSES16 > CGSES14 > CGSES12}

\subsubsection{Effect of Temperature}

From Table 6, it can be seen that $k$ increased while IE decreased with increasing the temperature from 20 to $80^{\circ} \mathrm{C}$ at all tested concentrations for CGSES12, CGSES14 and CGSES16. This was due to desorption mode of CGSES12, CGSES14 and CGSES16 from the MS surface. The maximum IE value occurred at the maximum concentration $(0.0025 \mathrm{M})$ and at the minimum temperature, i.e., $20^{\circ} \mathrm{C}$, for CGSES12, CGSES14 and CGSES16, respectively. Thus, these compounds may be regarded as effective inhibitors for MS in $1 \mathrm{M} \mathrm{HCl}$. The efficiency of these inhibitors at 20, 40, 60, and $80^{\circ} \mathrm{C}$ follows the order:

\section{CGSES16 > CGSES14 > CGSESS12}

The inhibition efficiencies obtained from polarization, EIS, and weight loss are compatible.

\subsection{Standard Adsorption Thermodynamic}

CGSES12, CGSES14 and CGSES16 exhibited inhibitive behavior through adsorption on the MS surface.

Therefore, many adsorption isotherms were utilized to fit the experimental data. The Langmuir isotherm was found to be the best model. The Langmuir isotherm is described by the following equation [49,50]:

$$
\frac{C}{\theta}=\frac{1}{K_{\mathrm{ads}}}+C
$$

where $K_{\mathrm{ads}}$ is the adsorption equilibrium constant, $C$ is the inhibitor concentration and $\theta$ is the surface coverage degree.

Linear lines were observed when plotting $(C / \theta)$ against $C$ (Figures 16-18). The intercept of these lines equaled $\left(1 / K_{\mathrm{ads}}\right)$, and the slope and linear correlation coefficients $\left(R^{2}\right)$ were very close to 1. This confirmed that the adsorption of CGSES12, CGSES14 and CGSES16 were consistent with the Langmuir isotherm. The $K_{\text {ads }}$ values are listed in Table 7 . Large $K_{\text {ads }}$ values occurred due to strong adsorption of CGSES12, CGSES14 and CGSES16 molecules on the MS surface. The $K_{\text {ads }}$ value increased with increasing the inhibitor concentration. This was due to increasing the numbers of CGSES12, CGSES14 and CGSES16 molecules on the MS surface. The $K_{\text {ads }}$ value decreased with increasing the temperature, which was due to a desorption of CGSES12, CGSES14 and CGSES16 molecules from the MS surface.

The standard adsorption free energy $\left(\Delta G_{\text {ads }}^{\circ}\right)$ was calculated using Equation (10) [51]:

$$
\Delta G_{\text {ads }}^{\circ}=-R T \ln \left(55.5 K_{\mathrm{ads}}\right)
$$

where the value 55.5 is the concentration of water in the test solution expressed in M [52]. 


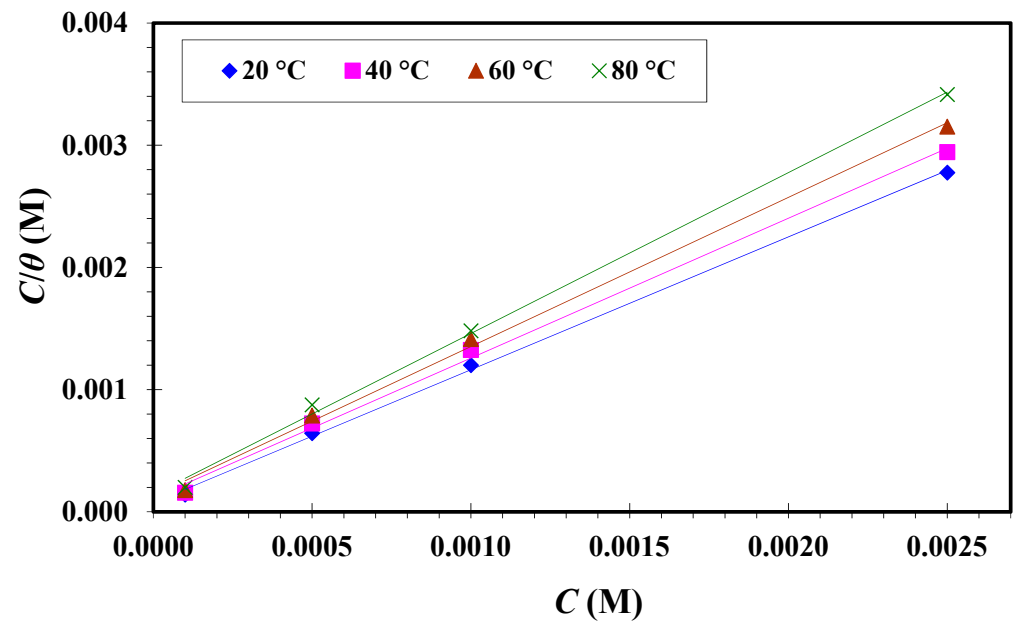

Figure 16. Langmuir isotherm adsorption model for CGSES12 on the MS surface in $1 \mathrm{M} \mathrm{HCl}$ at different temperatures.

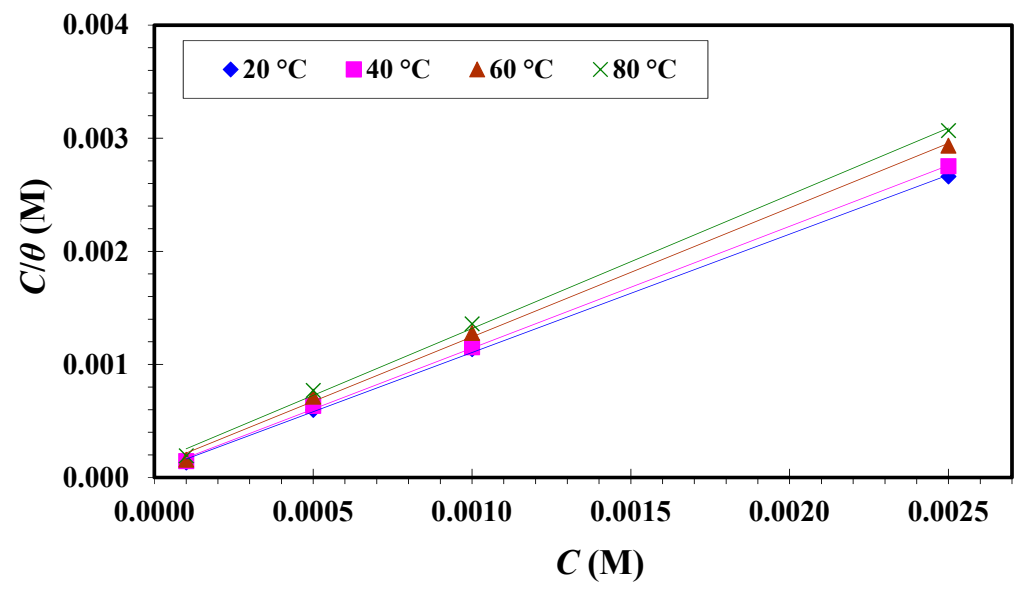

Figure 17. Langmuir isotherm adsorption model for CGSES14 on the MS surface in $1 \mathrm{M} \mathrm{HCl}$ at different temperatures.

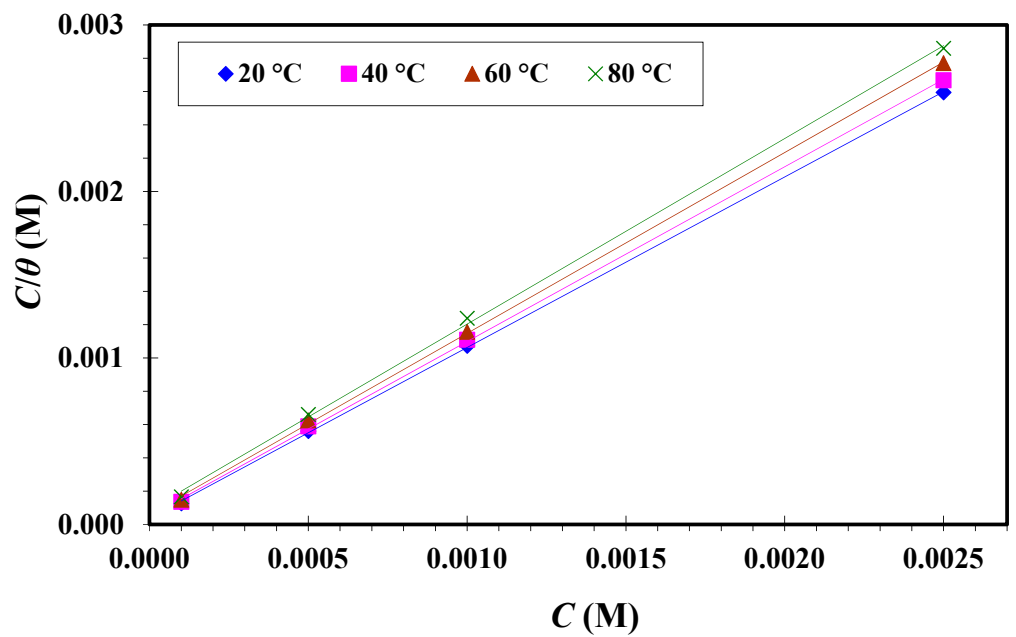

Figure 18. Langmuir isotherm adsorption model for CGSES14 on the carbon steel surface in $1 \mathrm{M} \mathrm{HCl}$ at different temperatures. 
Table 7. Standard thermodynamic parameters of adsorption on the MS surface in $1 \mathrm{M} \mathrm{HCl}$ containing different concentrations of the synthesized cationic gemini surfactants.

\begin{tabular}{|c|c|c|c|c|c|}
\hline Inhibitor & $\begin{array}{c}\text { Temperature } \\
\left({ }^{\circ} \mathrm{C}\right)\end{array}$ & $\begin{array}{c}K_{\mathrm{ads}} \\
\left(\mathbf{M}^{-1}\right)\end{array}$ & $\begin{array}{c}\Delta G_{\text {ads }}^{\circ} \\
\left(\mathrm{kJ} \mathrm{mol} \mathrm{mol}^{-1}\right)\end{array}$ & $\begin{array}{c}\Delta H_{\text {ads }}^{\circ} \\
\left(\mathrm{kJ} \mathrm{mol}^{-1}\right)\end{array}$ & $\begin{array}{c}\Delta S^{\circ} \text { ads } \\
\left(\mathrm{J} \mathrm{mol}^{-1} \mathrm{~K}^{-1}\right)\end{array}$ \\
\hline \multirow{4}{*}{ CGSES12 } & 20 & 17,097 & -33.53 & \multirow{4}{*}{-12.50} & 71.77 \\
\hline & 40 & 15,022 & -35.48 & & 73.42 \\
\hline & 60 & 9858 & -36.58 & & 72.31 \\
\hline & 80 & 7398 & -37.93 & & 72.05 \\
\hline \multirow{4}{*}{ CGSES14 } & 20 & 26,074 & -34.55 & \multirow{4}{*}{-11.70} & 78.02 \\
\hline & 40 & 20,439 & -36.28 & & 78.55 \\
\hline & 60 & 16,225 & -37.96 & & 78.87 \\
\hline & 80 & 11,295 & -39.18 & & 77.85 \\
\hline \multirow{4}{*}{ CGSES16 } & 20 & 37,549 & -35.44 & \multirow{4}{*}{-14.49} & 71.51 \\
\hline & 40 & 26,806 & -36.99 & & 71.87 \\
\hline & 60 & 19,746 & -38.50 & & 72.11 \\
\hline & 80 & 13,460 & -39.69 & & 71.39 \\
\hline
\end{tabular}

The calculated $\Delta G^{\circ}$ ads values for CGSES12, CGSES14 and CGSES16 are listed in Table 7 . The $\Delta G^{\circ}$ ads values were in a range of -33.53 to $-39.18 \mathrm{~kJ} \mathrm{~mol}^{-1}$, due to the fact that the adsorption of CGSES12, CGSES14 and CGSES16 was a combination of physical and chemical processes [53-55].

$\Delta H^{\circ}$ ads was calculated from Van't Hoff equation [56,57]:

$$
\ln K_{\mathrm{ads}}=\left(\frac{-\Delta H_{\mathrm{ads}}^{\mathrm{o}}}{R T}\right)+\text { constant }
$$

Plotting $\ln K_{\text {ads }}$ vs. $\frac{1}{T}$ yielded straight lines, as shown in Figure 19. The slope of the straight line is equal to $\left(\frac{-\Delta H_{\mathrm{ads}}^{\mathrm{o}}}{R}\right)$. The negative $\Delta H^{\circ}$ ads values indicated that the adsorption of CGSES12, CGSES14 and CGSES16 was an exothermic process.

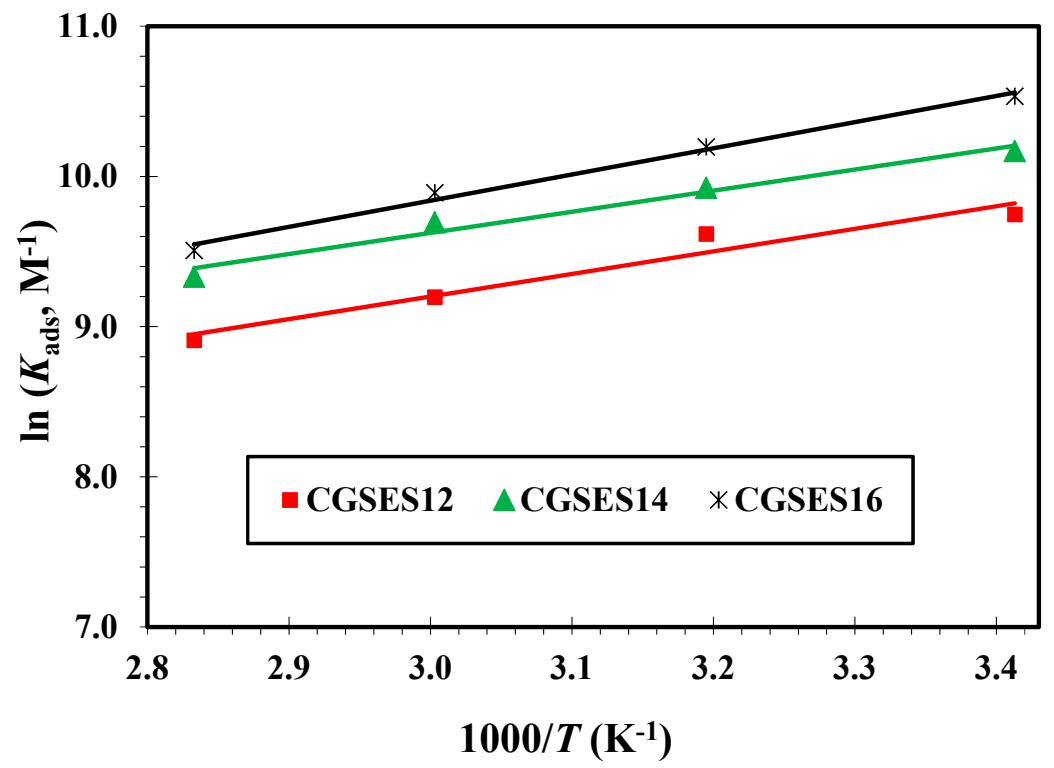

Figure 19. The relationship between $\ln K_{\mathrm{ads}}$ and $1 / \mathrm{T}$ for $\mathrm{MS}$ in a $1 \mathrm{M} \mathrm{HCl}$ solution containing different concentrations of the synthesized cationic gemini surfactants on the $\mathrm{MS}$ surface in $1 \mathrm{M} \mathrm{HCl}$ at different temperatures. 
$\Delta S^{\circ}$ ads was calculated from the following equation [58]:

$$
\Delta G_{\mathrm{ads}}^{\mathrm{o}}=\Delta H_{\mathrm{ads}}^{\mathrm{o}}-T \Delta S_{\mathrm{ads}}^{\mathrm{o}}
$$

The positive value of $\Delta S^{\circ}$ ads listed in Table 7 indicates an increase in the disorder of CGSES12, CGSES14 and CGSES16 during the adsorption process.

\subsection{Activation Energy $\left(E_{a}\right)$}

$E_{\mathrm{a}}$ was calculated using the Arrhenius equation [59]:

$$
\ln k=\frac{-E_{\mathrm{a}}}{R T}+\ln A
$$

A plot of lnk vs. $(1 / T)$ yielded straight lines, as shown in Figures 20-22. The slope of the straight line equaled $\left(-E_{\mathrm{a}} / R\right)$. The $E_{\mathrm{a}}$ values were calculated and are listed in Table 8 . The $E_{\mathrm{a}}$ values in the presence of CGSES12, CGSES14 and CGSES16 were higher than in their absence. This confirmed the adsorption of CGSES12, CGSES14 and CGSES16 on the MS surface in $1 \mathrm{M} \mathrm{HCl} \mathrm{[60].}$

Table 8. Activation energy $\left(E_{\mathrm{a}}, \mathrm{kJ} \mathrm{mol}^{-1}\right)$ values for $\mathrm{MS}$ in $1 \mathrm{M} \mathrm{HCl}$ in the absence and presence of

\begin{tabular}{|c|c|c|c|}
\hline \multirow{2}{*}{$\begin{array}{l}\text { Conc. of Inhibitor } \\
\text { (M) }\end{array}$} & \multicolumn{3}{|c|}{ 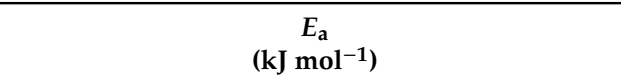 } \\
\hline & CGSES12 & CGSES14 & CGSES16 \\
\hline $1 \mathrm{M} \mathrm{HCl}$ & 36.91 & 36.91 & 36.91 \\
\hline $1.0 \times 10^{-4}$ & 46.28 & 46.13 & 50.11 \\
\hline $5.0 \times 10^{-4}$ & 48.36 & 48.59 & 52.07 \\
\hline $1.0 \times 10^{-3}$ & 49.31 & 51.82 & 56.74 \\
\hline $2.5 \times 10^{-3}$ & 53.41 & 54.95 & 59.32 \\
\hline
\end{tabular}
different concentrations of the synthesized cationic gemini surfactants.

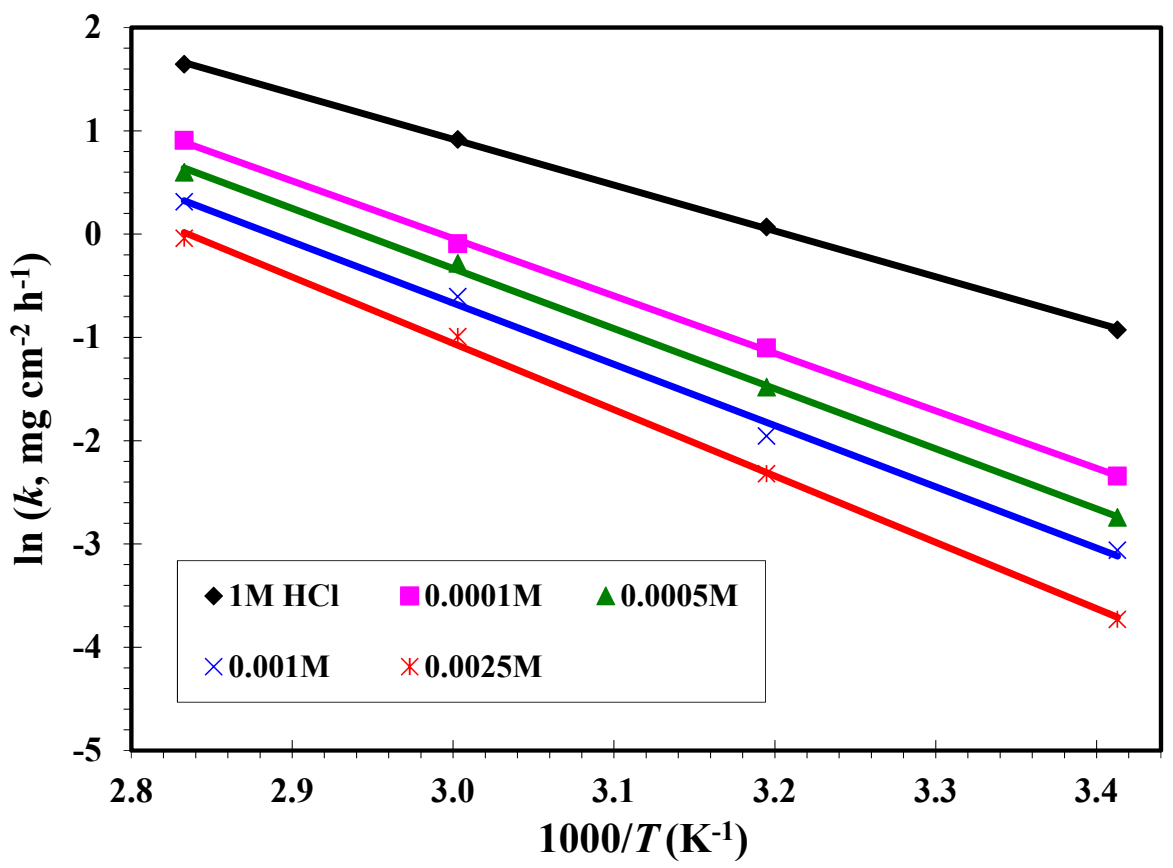

Figure 20. In $k$ versus $1 / T$ curves for MS dissolution in the absence and presence of different concentrations of CGSES12 in $1 \mathrm{M} \mathrm{HCl}$ solution. 


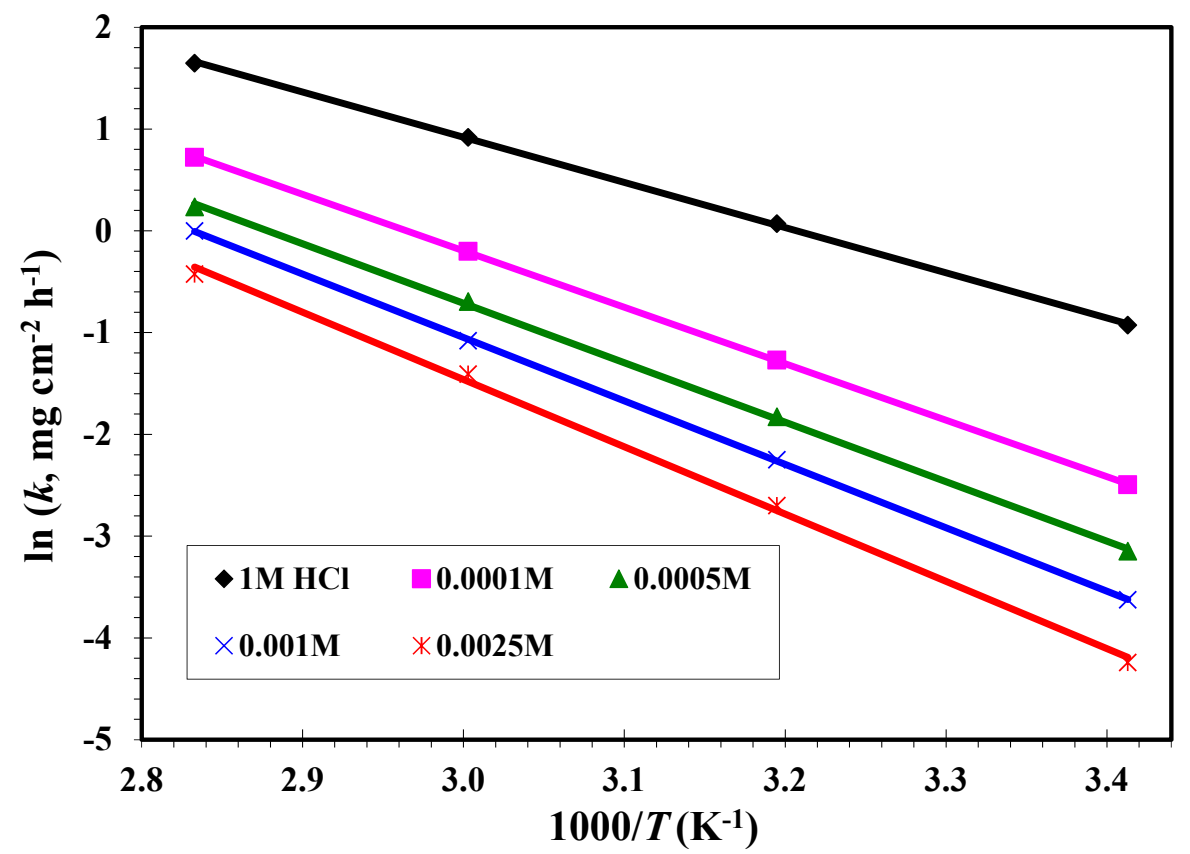

Figure 21. $\ln k$ versus $1 / T$ curves for MS dissolution in the absence and presence of different concentrations of CGSES14 in $1 \mathrm{M} \mathrm{HCl}$ solution.

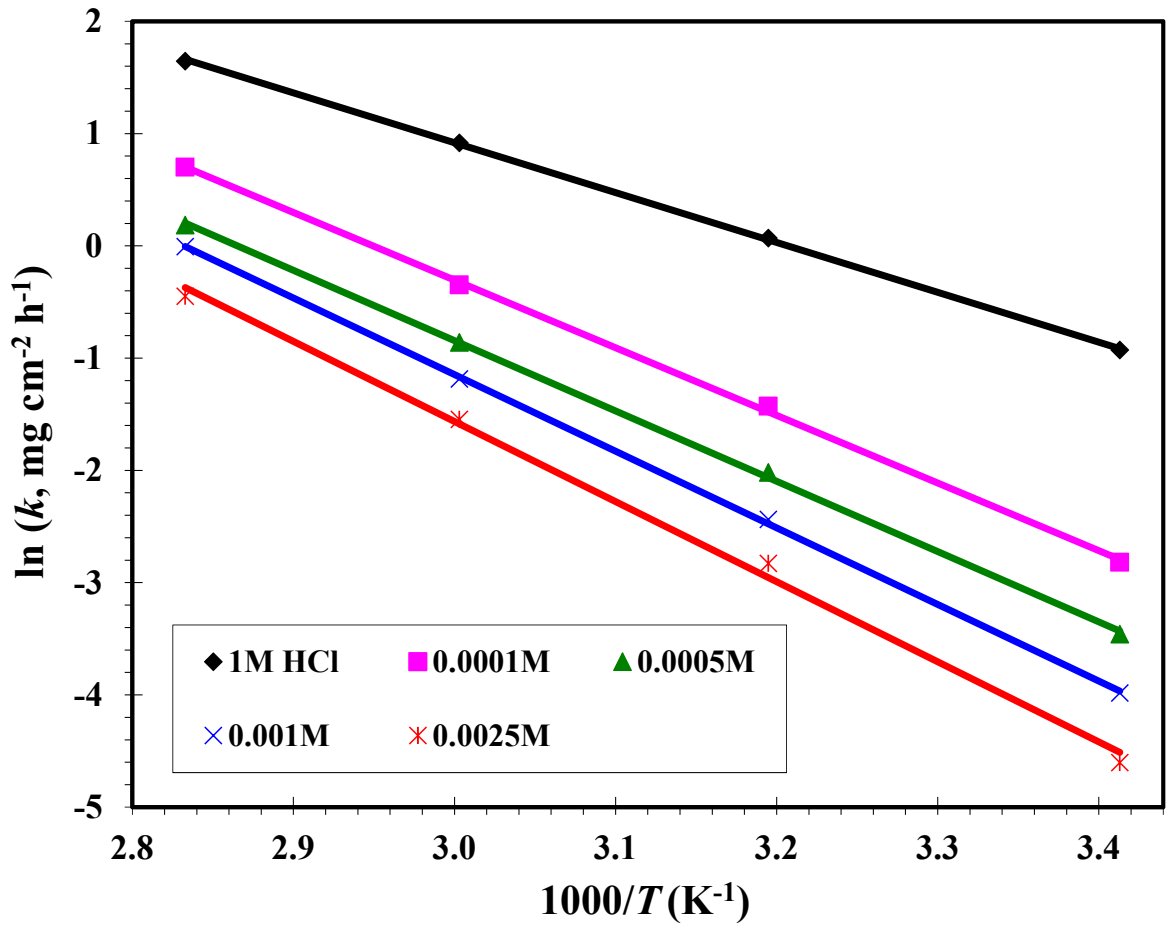

Figure 22. In $k$ versus $1 / T$ curves for MS dissolution in the absence and presence of different concentrations of CGSES16 in $1 \mathrm{M} \mathrm{HCl}$ solution.

\subsection{Surface Active Properties}

\subsubsection{Critical Micelle Concentration $\left(C_{\mathrm{cmc}}\right)$ and Effectiveness $\left(\pi_{\mathrm{cmc}}\right)$}

The surface tension $(\gamma)$ vs. $(\log C)$, as signified in Figure 23, was drawn to determine the $C_{\mathrm{cmc}}$ value. $C_{\mathrm{cmc}}$ was determined from the break point of the plots, as listed in Table 9. It was observed that 
CGSES12, CGSES14 and CGSES16 strongly reduced the surface tension. The effectiveness $\left(\pi_{\mathrm{cmc}}\right)$ at $C_{\mathrm{cmc}}$, is estimated from the following equation [61,62]:

$$
\pi_{\mathrm{cmc}}=\gamma_{\mathrm{o}}-\gamma_{\mathrm{cmc}}
$$

where $\gamma_{\mathrm{o}}$ and $\gamma_{\mathrm{cmc}}$ are the surface tension of pure water and at $C_{\mathrm{cmc}}$.

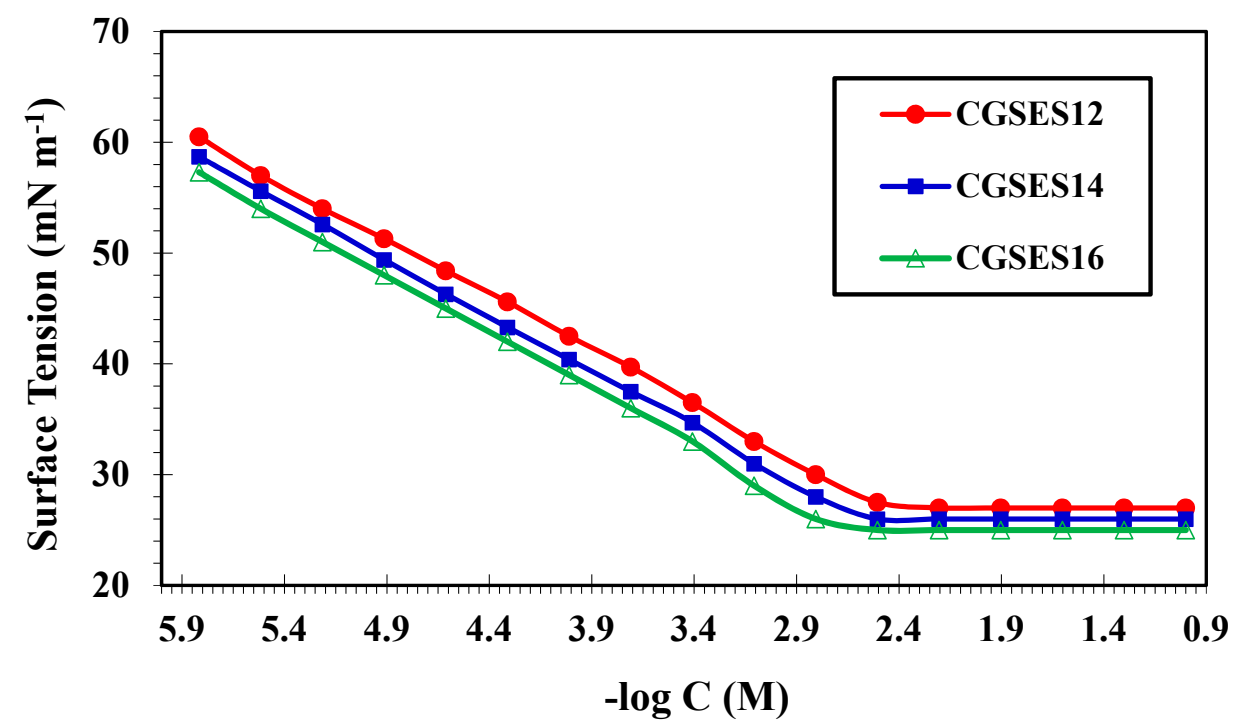

Figure 23. Variation of the surface tension with the concentration of the synthesized cationic gemini surfactant in double-distilled water at $25^{\circ} \mathrm{C}$.

Table 9. Surface tension parameters of the synthesized cationic gemini surfactants in double-distilled water at $25^{\circ} \mathrm{C}$.

\begin{tabular}{|c|c|c|c|c|c|}
\hline Inhibitor name & $\begin{array}{c}C_{\mathrm{cmc}} \times 10^{3} \\
(\mathrm{M})\end{array}$ & $\begin{array}{c}\gamma_{\mathrm{cmc}} \\
\left(\mathrm{mN} \mathrm{m}^{-1}\right)\end{array}$ & $\begin{array}{c}\pi_{\mathrm{cmc}} \\
\left(\mathrm{mN} \mathrm{m}^{-1}\right)\end{array}$ & $\begin{array}{l}\Gamma_{\max } \times 10^{11} \\
\left(\mathrm{~mol} \mathrm{~cm} \mathrm{~cm}^{-2}\right)\end{array}$ & $\begin{array}{l}A_{\min } \\
\left(\mathrm{nm}^{2}\right)\end{array}$ \\
\hline CGSES12 & 2.60 & 27.0 & 45.0 & 5.82 & 2.85 \\
\hline CGSES14 & 1.70 & 26.2 & 45.8 & 5.92 & 2.81 \\
\hline CGSES16 & 1.10 & 25.4 & 46.6 & 6.01 & 2.76 \\
\hline
\end{tabular}

The values of $\gamma_{\mathrm{cmc}}$ and $\pi_{\mathrm{cmc}}$ for CGSES12, CGSES14 and CGSES16 are given in Table 9. It was found that $C_{\mathrm{cmc}}$ decreased while $\pi_{\mathrm{cmc}}$ increased with increasing the hydrophobic chain.

3.7.2. Surface Excess $\left(\Gamma_{\max }\right)$ and Minimum Surface Area $\left(\mathrm{A}_{\min }\right)$

$\Gamma_{\max }$ and $A_{\min }$ are the concentration and minimum area of the surfactant at the air-solution interface. $\Gamma_{\max }$ and $A_{\min }$ were computed using Gibbs's adsorption [63,64]:

$$
\begin{gathered}
\Gamma_{\max }=\left(\frac{-1}{n R T}\right)\left(\frac{\mathrm{d} \gamma}{\mathrm{d} \ln C}\right) \\
A_{\min }=\frac{10^{14}}{N_{\mathrm{A}} \Gamma_{\max }}
\end{gathered}
$$

By plotting $\gamma$ against $\ln C$, the slope refers to $d \gamma / d \ln C$. The surfactant concentration at the surface was always higher than that in the bulk solution [65-67].

The $\Gamma_{\max }$ and $A_{\min }$ values were calculated and are shown in Table 9. It was found that the $\Gamma_{\max }$ value increased while $A_{\min }$ decreased with increasing the hydrophobic chain. These results indicate that CGSES12, CGSES14 and CGSES16 are good surfactants. 
3.8. Comparison Between the Synthseized Surfactants and Other Inhibitors Reported in the Literature (Correlation Structure and Efficiency-Surface Activity)

The effectiveness of the synthesized inhibitors is dependent on their chemical structure and surface properties. CGSES12, CGSES14 and CGSES16, in addition to the fatty alkyl chain, were adsorbed on the MS surface by a lone pairs of electrons of $\mathrm{N}$ and $\mathrm{O}$ atoms, $\mathrm{N}^{+}$and $\mathrm{Cl}^{-}$ions. The $\Delta G^{\circ}$ ads values of CGSES12, CGSES14 and CGSES16 were $-33.53,-34.55$ and $-35.44 \mathrm{~kJ} \mathrm{~mol}^{-1}$ at $20{ }^{\circ} \mathrm{C}$, and gradually declined to $-37.93,-39.18$ and $-39.69 \mathrm{~kJ} \mathrm{~mol}^{-1}$ at $80^{\circ} \mathrm{C}$, respectively. Furthermore, the $\Delta H^{\circ}$ ads values of CGSES12, CGSES14 and CGSES16 were negative and low $\left(-12.50,-11.70\right.$ and $\left.-14.49 \mathrm{~kJ} \mathrm{~mol}^{-1}\right)$. Such values suggest that depending on the temperature value, the adsorption of CGSES12, CGSES14 and CGSES16 was physical and chemical in nature. The physical adsorption between the charged MS surface and the charged atoms $\left(\mathrm{N}^{+}\right.$and $\left.\mathrm{Cl}^{-}\right)$of CGSES12, CGSES14 and CGSES16 occurred at low temperatures. By increasing the temperature, the chemical adsorption of CGSES12, CGSES14 and CGSES16 arose due to donor-acceptor interactions between the free electron pairs of the hetero atoms $(\mathrm{O}$ and $\mathrm{N})$ and vacant d-orbitals of iron.

The corrosion inhibition efficiency (IE) and reduction of surface tension (effectiveness, $\pi_{\mathrm{cmc}}$ ) of these inhibitors follows the order CGSES16 > CGSES14 > CGSES12. The adsorption of these cationic gemini surfactants resulted in well packed, adsorbed layers, a greater covered surface area and more homogeneous adsorbed film, as shown in Figure 24.

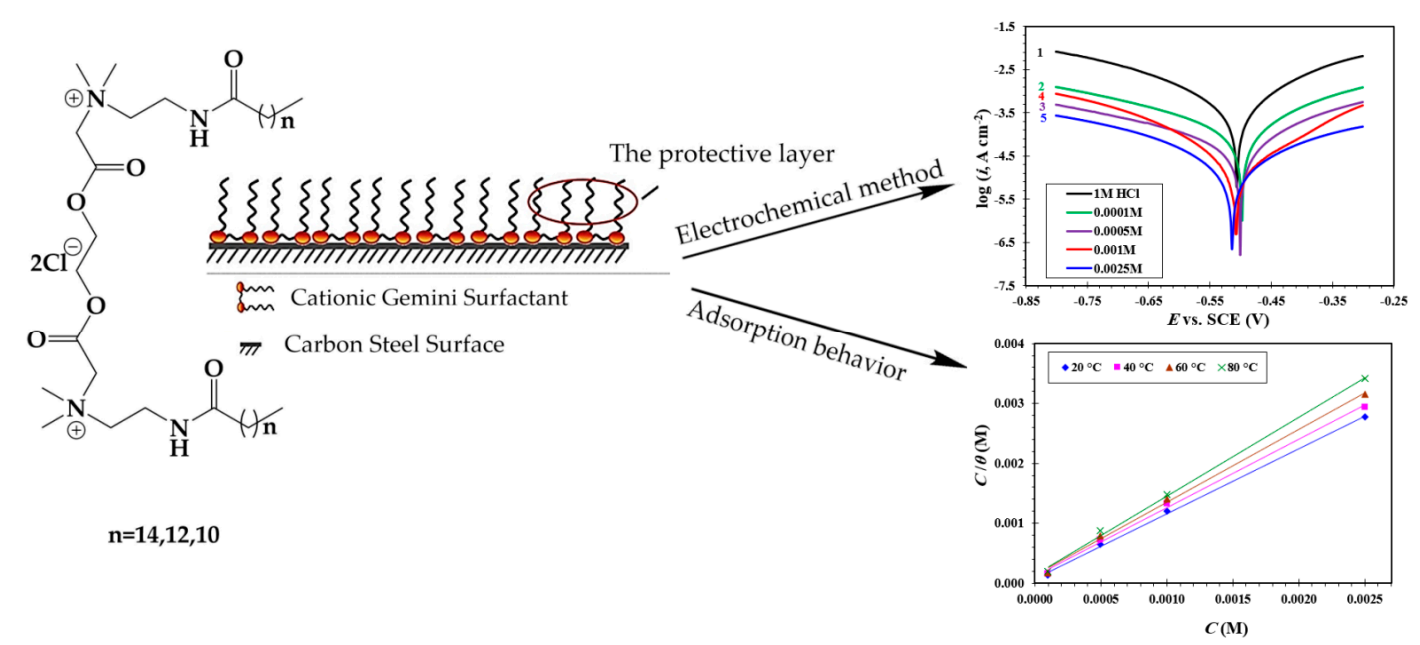

Figure 24. Dependence of the efficiency of the synthesized inhibitors on the chemical structure and surface properties.

Surfactants are very effective corrosion inhibitors which lower the surface tension (or interfacial tension) between the corrosive medium and the MS surface. The evaluation of surfactants as corrosion inhibitors usually uses concentrations below critical micelle concentration $\left(C_{\mathrm{cmc}}\right)$ because the surfactants molecules after $C_{\mathrm{cmc}}$ form micelle in the majority of tested solutions (a distinctive property of surfactants). Therefore, any concentration greater than $C_{\mathrm{cmc}}$ will not increase the inhibition efficiency. On the other hand, organic compounds disperse almost at the same rate, both in bulk solution and at the interface. A comparison between the tested compounds and other inhibitors reported in the literature for anticorrosion protection of steel under the same experimental conditions is summarized in Table 10. This comparison shows that synthesized cationic gemini surfactants were more effective as corrosion inhibitors compared with other surfactants. 
Table 10. The comparison between the tested compounds and other inhibitors reported in the literature for anti-corrosion protection of steel at the same experiment conditions.

\begin{tabular}{|c|c|c|}
\hline Inhibitor Name & IE (\%) & Reference \\
\hline (E)-decyl-4-[(2-hydroxyethylamino) methyl]-N,N dimethyl benzenaminium bromide & 90.26 & [68] \\
\hline (E)-dodecyl-4-[(2-hydro-xyethylamino)methyl]-N,N-dimethyl benzenaminium bromide & 90.95 & [68] \\
\hline (E)-hexadecyl4-[(2-hydro-xyethylamino)methyl]-N,N-dimethyl benzenaminium bromide & 93.12 & [68] \\
\hline N,N-bis(2-hydroxyethyl)-N-octylbenzo[d]thiazol 2-amonium bromide & 87.26 & [69] \\
\hline N,N-bis(2-hydroxyethyl)-N-decylbenzo[d]thiazol 2-amonium bromide & 91.46 & [69] \\
\hline N,N-bis(2-hydroxyethyl)-N-dodecylbenzo[d] thiazol-2 -amonium bromide & 94.35 & [69] \\
\hline $\mathrm{N}$-(3-(benzylideneamino)propyl)-N,N-dimethyldecan-1-ammonium bromide & 82.93 & [70] \\
\hline $\mathrm{N}$-(3-(benzylideneamino)propyl)-N,N-dimethyldodecan-1-ammonium bromide & 87.45 & [70] \\
\hline N-(3-(benzylideneamino)propyl)-N,N-dimethylhexadecan-1-ammonium bromide & 88.02 & [70] \\
\hline 2-2'-(Ethane-1,2-diyl bis(oxy)) bis(N-(2-dodecanamidoethyl)-N,N-dimethyl-2-oxoethan-1-aminium) dichloride (CGSES12) & 93.93 & This work \\
\hline 2-2'-(Ethane-1,2-diyl bis(oxy)) bis(N-(2-tetradecanamidoethyl)-N,N-dimethyl-2-oxoethan-1-aminium) dichloride (CGSES14) & 96.36 & This work \\
\hline 2-2'-(Ethane-1,2-diyl bis(oxy)) bis(N-(2-hexadecanamidoethyl)-N,N-dimethyl-2-oxoethan-1-aminium) dichloride (CGSES16) & 97.46 & This work \\
\hline
\end{tabular}




\section{Conclusions}

The present work concludes with the following points:

1. Three new cationic gemini surfactants with ester spacer type of 2-2'-(ethane-1,2-diyl bis(oxy)) bis(N-(2-alkanamidoethyl)-N,N-dimethyl-2-oxoethan-1-aminium)) dichloride) (CGSES12, CGSES14, and CGSES16) based on N,N dimethyl fatty amido ethylamine were synthesized using a three-step reaction method, and were characterized by FT-IR, ${ }^{1} \mathrm{HNMR},{ }^{13} \mathrm{CNMR}$ spectroscopies.

2. The inhibition performance of the three surfactants was studied by weight loss and electrochemical measurements.

3. The results showed that CGSES12, CGSES14 and CGSES16 behaved as effective inhibitors and surface agents.

4. The maximum efficiency was higher than $94 \%$ at $2.5 \mathrm{mM}$, and the inhibition order was CGSES16 > CGSES14 > CGSES12. This was due to the increment in hydrophobicity of the gemini surfactants.

5. Their adsorption on the MS surface followed the Langmuir isotherm. CGSES12, CGSES14 and CGSES16 can be considered mixed type inhibitors.

6. The presence of CGSES12, CGSES14 and CGSES16 increased the charge transfer resistance and decreased the corrosion rate. The adsorption focused on the heteroatoms and the surface properties of the cationic gemini surfactants.

7. $\pi_{\mathrm{cmc}}$ and $\Gamma_{\max }$ increased, while $C_{\mathrm{cmc}}$ and $A_{\min }$ decreased with increasing the hydrophobic chain.

Supplementary Materials: The following are available online at http://www.mdpi.com/1996-1944/13/12/2790/s1, Figure S1. FT-IR Spectra N-(2-(dimethylamino)ethyl)dodecanamide, Figure S2. FT-IR Spectra for N-(2-(dimethylamino)ethyl)tetradecanamide, Figure S3. FT-IR Spectra for N-(2-(dimethylamino)ethyl) hexadecanamide, Figure S4. FT-IR Spectra for Ethane-1,2-diyl bis(2-chloroethanoat), Figure S5. FT-IR Spectra for (2-2'-(ethane-1,2-diylbis(oxy))bis(N-(2-dodecanamidoethyl)-N,N-dimethyl-2-oxoethan-1-aminium)) dichloride, Figure S6. FT-IR Spectra for 2-2'-(ethane-1,2-diylbis(oxy))bis(N-(2-hexadecanamidoethy)-N,N-dimethyl-2-oxoethan -1-aminium) dichloride, Figure S7. ${ }^{1} \mathrm{H}-\mathrm{NMR}$ Spectra for N-(2-(dimethylamino)ethyl)dodecanamide, Figure S8. ${ }^{1}$ H-NMR Spectra for N-(2-(dimethylamino)ethyl)tetradecanamid, Figure S9. ${ }^{1} \mathrm{H}-\mathrm{NMR}$ Spectra for N-(2(dimethylamino)ethyl) hexadecanamide), Figure S10. ${ }^{1} \mathrm{H}-\mathrm{NMR}$ Spectra for Ethane-1,2-diyl bis(2-chloroethanoat), Figure S11. ${ }^{1} \mathrm{H}-\mathrm{NMR}$ Spectra for (2-2'-(ethane-1,2-diylbis(oxy))bis(N-(2-dodecanamidoethyl)-N,N-dimethyl-2 -oxoethan-1-aminium)) dichloride, Figure S12. ${ }^{13}$ C-NMR Spectra for. N-(2-(dimethylamino)ethyl) hexadecanamide, Figure S13. Mass spectra for2-2'-(ethane-1,2-diylbis(oxy))bis(N-(2-dodecanamidoethyl)-N,N -dimethyl-2-oxoethan-1-aminium)) dichloride, Figure S14 Mass spectra for 2,2'-(ethane-1,2-diylbis(oxy))bis(N,N-dimethyl-2-oxo-N-(2-tetradecanamidoethyl)ethan-1-aminium)di chloride.

Author Contributions: E.E.B. and M.A.H.; methodology, N.S.B.-H. and E.E.B.; formal analysis, E.E.B. and N.S.B.-H.; software, N.S.B.-H. and M.A.H.; investigation, E.E.B. and N.S.B.-H.; data curation, E.E.B. and M.A.H.; Writing-original draft preparation, N.S.B.-H. and E.E.B.; writing-review and editing, E.E.B. and M.A.H.; supervision, E.E.B.; project administration, E.E.B. All authors have read and agreed to the published version of the manuscript.

Funding: This research received no external funding.

Conflicts of Interest: The authors declare no conflict of interest.

\section{References}

1. Wang, F.E. Bonding Theory for Metals and Alloys, 2nd ed.; Elsevier: Amsterdam, The Netherlands, 2019; pp. 157-191.

2. El-Tabei, A.S.; Hegazy, M.A. Synthesis and characterization of a novel nonionic gemini surfactant as corrosion inhibitor for MS in acidic solution. Chem. Eng. Commun. 2015, 7, 851-863. [CrossRef]

3. Rbaa, M.; Lgaz, H.; Kacimi, Y.e.; Lakhrissi, B.; Bentiss, F.; Zarrouk, A. Synthesis, characterization and corrosion inhibition studies of novel 8-hydroxyquinoline derivatives on the acidic corrosion of mild steel: Experimental and computational studies. Mater. Discov. 2018, 12, 43-54. [CrossRef]

4. Labena, A.; Hegazy, M.A.; Sami, R.M.; Hozzein, W.N. Multiple applications of a novel cationic gemini surfactant: Anti-microbial, anti-biofilm, biocide, salinity corrosion inhibitor, biofilm's dispersion (Part II). Molecules 2020, 25, 1348-1363. [CrossRef] 
5. Dehghani, A.; Bahlakeh, G.; Ramezanzadeh, B.; Ramezanzadeh, M. A combined experimental and theoretical study of green corrosion inhibition of mild steel in $\mathrm{HCl}$ solution by aqueous Citrullus lanatus fruit (CLF) extract. J. Mol. Liq. 2019, 279, 603-624. [CrossRef]

6. Shaw, P.; Obot, I.B.; Yadav, M. Functionalized 2-hydrazinobenzothiazole with carbohydrates as a corrosion inhibitor: Electrochemical, XPS, DFT and Monte Carlo simulation studies. Mater. Chem. Front. 2019, 3, 931-940. [CrossRef]

7. Hegazy, M.A.; El-Etre, A.Y.; Berry, K.M. Novel inhibitors for MS pipelines corrosion during acidizing of oil and gas wells. J. Basic Environ. Sci. 2014, 1, 174-189.

8. Hegazy, M.A.; El-Etre, A.Y.; El-Shafaie, M.; Berry, K.M. Novel cationic surfactants for MS pipelines corrosion inhibition during acidization of oil and gas wells. J. Mol. Liq. 2016, 214, 347-356. [CrossRef]

9. Crevolin, P.; Francis, R.; Garrity, K.; Hall, S.; Kinzie, R.; Kroon, D.; Lee, L.; Rampton, F.; Riddle, D.; Tanabe, H.; et al. International Measures of Prevention, Application and Economics of Corrosion Technologies tudy. In NACE-International-Report; NACE Internationa: Houston, TX, USA, 2016.

10. El-Reedy, M.A. Offshore Structures: Design, Construction and Maintenance, 1st ed.; Gulf Professional Publishing: Houston, TX, USA, 2012.

11. Khalaf, M.M.; Tantawy, A.H.; Soliman, K.A.; El-Lateef, H.M.A. Cationic gemini-surfactants based on waste cooking oil as new 'green' inhibitors for N80-steel corrosion in sulphuric acid: A combined empirical and theoretical approaches. J. Mol. Struct. 2020, 12035, 127442. [CrossRef]

12. Abdallah, M.; Eltass, H.M.; Hegazy, M.A.; Ahmed, H. Adsorption and inhibition effect of novel cationic surfactant for pipelines MS in acidic solution. Prot. Met. Phys. Chem. Surf. 2016, 52, 721-730. [CrossRef]

13. Shalabi, K.; Helmy, A.M.; El-Askalany, A.H.; Shahba, M.M. New pyridinium bromide mono-cationic surfactant as corrosion inhibitor for MS during chemical cleaning: Experimental and theoretical studies. J. Mol. Liq. 2019, 2931, 111480. [CrossRef]

14. Shaban, S.M.; Aiad, I.; Moustafa, A.H.; Aljoboury, O.H. Aljoboury, Some alginates polymeric cationic surfactants; surface study and their evaluation as biocide and corrosion inhibitors. J. Mol. Liq. 2019, 273, 164-176. [CrossRef]

15. Hegazy, M.A.; Abdallah, M.; Alfakeer, M.; Ahmed, H. Corrosion inhibition performance of a novel cationic surfactant for protection of MS pipeline in acidic media. Int. J. Electrochem. Sci. 2018, 13, 6824-6842. [CrossRef]

16. Fouda, A.S.; Elmorsi, M.A.; Shaban, S.M.; Fayed, T.; Azazy, O. Evaluation of N-(3-(dimethyl hexadecyl ammonio)propyl) palmitamide bromide as cationic surfactant corrosion inhibitor for API N80 steel in acidic environment. Egypt. J. Pet. 2018, 27, 683-694. [CrossRef]

17. Hegazy, M.A.; Rehim, S.S.A.e.; Badawi, A.M.; Ahmed, M.Y. Studying the corrosion inhibition of MS in hydrochloric acid solution by 1-dodecyl-methyl-1H-benzo[d][1,2,3]triazole-1-ium bromide. RSC Adv. 2015, 5, 49070-49079. [CrossRef]

18. Negm, N.A.; Migahed, M.A.; Farag, R.K.; Fadda, A.A.; Awad, M.K.; Shaban, M.M. High performance corrosion inhibition of novel tricationic surfactants on MSin formation water: Electrochemical and computational evaluations. J. Mol. Liq. 2018, 262, 363-375. [CrossRef]

19. Badr, E.E.; Kandeel, E.M.; El-Sadek, B.M. Novel gemini cationic surfactants based on N, N-dimethyl fatty hydrazide and 1,3-dibromopropane: Synthesis, evaluation of surface and antimicrobial properties. J Oleo Sci. 2010, 59, 647-652. [CrossRef]

20. Tawfik, S.M.; Abd-Elaal, A.A.; Shaban, S.M.; Roshdy, A.A. Surface, thermodynamic and biological activities of some synthesized Gemini quaternary ammonium salts based on polyethylene glycol. J. Ind. Eng. Chem. 2015, 30, 112-119. [CrossRef]

21. Hegazy, M.A.; Atlam, F.M. Three novel bolaamphiphiles as corrosion inhibitors for MS in hydrochloric acid: Experimental and computational studies. J. Mol. Liq. 2016, 218, 649-662. [CrossRef]

22. Ren, C.; Wang, F.; Zhang, Z.; Nie, H.; Li, N.; Cui, M. Synthesis surface activity and aggregation behavior of Gemini imidazolium surfactants 1,3-bis(3-alkylimidazolium-1-yl) propane bromide. Colloids Surf. A Physicochem. Eng. Asp. 2015, 467, 1-8. [CrossRef]

23. El-Lateef, H.M.A.; Soliman, K.A.; Tantawy, A.H. Novel synthesized Schiff Base-based cationic gemini surfactants: Electrochemical investigation, theoretical modeling and applicability as biodegradable inhibitors for mild steel against acidic corrosion. J. Mol. Liq. 2017, 232, 478-498. [CrossRef] 
24. Hegazy, M.; Samy, R.; Labena, A.; Wadaan, M.A.; Hozzein, W.N. 4,4'-((1E,5E)-pentane-1,5-diylidene)bis(azanylylidene))bis(1-dodecylpyridin-1-ium) bromide as a novel corrosion inhibitor in an acidic solution (Part I). Mater. Sci. Eng. C 2020, 110, 110673. [CrossRef] [PubMed]

25. Sonntag, N.O. Reactions of fatty acid chlorides: II. Synthesis of monohydrazides or dihydrazides by acylation of hydrazine hydrate with saturated fatty acid chlorides. J. Am. Oil Chem. Soc. 1968, 45, 571-574. [CrossRef]

26. Gao, Z.; Tai, S.; Zhang, Q.; Zhao, Y.; Lü, B.; Ge, Y.; Tang, X. Synthesis and surface activity of biquaternary ammonium salt Gemini surfactants with ester bond. Wuhan Univ. J. Nat. Sci. 2008, 13, 227-231. [CrossRef]

27. Bhadani, A.; Endo, T.; Sakai, K.; Sakai, H.; Abe, M. Synthesis and dilute aqueous solution properties of ester functionalized cationic Gemini surfactants having different ethylene oxide units as spacer. Colloid Polym. Sci. 2014, 292, 1685-1692. [CrossRef]

28. Labena, A.; Hegazy, M.A.; Horn, H.; Müller, E. Cationic gemini surfactant as a corrosion inhibitor and a biocide for high salinity sulfidogenic bacteria originating from an oil-field water tank. J. Surfactants Deterg. 2014, 17, 419-431. [CrossRef]

29. Zhao, Y.; Yue, X.; Wang, X.; Huang, D.; Chen, X. Micelle formation by N-alkyl-N-methylpiperidinium bromide ionic liquids in aqueous solution. Colloids Surf. A Physicochem. Eng. Asp. 2012, 412, 90-95. [CrossRef]

30. Azzam, E.M.S.; Hegazy, M.A.; Kandil, N.G.; Badawi, A.M.; Sami, R.M. The performance of hydrophobic and hydrophilic moieties in synthesized thiol cationic surfactants on corrosion inhibition of MS in $\mathrm{HCl}$. Egypt. J. Pet. 2015, 24, 493-503. [CrossRef]

31. Hegazy, M.A.; Badawi, A.M.; Rehim, S.S.A.e.; Kamel, W.M. Influence of copper nanoparticles capped by cationic surfactant as modifier for steel anti-corrosion paints. Egypt. J. Pet. 2013, 22, 549-556. [CrossRef]

32. Han, P.; Li, W.; Tian, H.; Gao, X.; Ding, R.; Xiong, C.; Song, L.; Zhang, X.; Wang, W.; Chen, C. Comparison of inhibition performance of pyridine derivatives containing hydroxyl and sulfhydryl groups: Experimental and theoretical calculations Influence of copper nanoparticles capped by cationic surfactant as modifier for steel anti-corrosion paints. Mater. Chem. Phys. 2018, 214, 345-354. [CrossRef]

33. Hegazy, M.A.; Azzam, E.M.S.; Kandil, N.G.; Badawi, A.M.; Sami, R.M. Corrosion inhibition of MS pipelines by some new amphoteric and di-cationic surfactants in acidic solution by chemical and electrochemical methods Influence of copper nanoparticles capped by cationic surfactant as modifier for steel anti-corrosion paints. J. Surfactants Deterg. 2016, 19, 861-871. [CrossRef]

34. Aslam, R.; Mobin, M.; Aslam, J.; Lgaz, H.; Chung, I.-M. Inhibitory effect of sodium carboxymethylcellulose and synergistic biodegradable gemini surfactants as effective inhibitors for MS corrosion in $1 \mathrm{M} \mathrm{HCl}$. J. Mater. Res. Technol. 2019, 8, 4521-4533. [CrossRef]

35. Kaczerewska, O.; Leiva-Garcia, R.; Akid, R.; Brycki, B.; Pospieszny, T. Effectiveness of O-bridged cationic gemini surfactants as corrosion inhibitors for stainless steel in $3 \mathrm{M} \mathrm{HCl}$ : Experimental and theoretical studies. J. Mol. Liq. 2018, 249, 1113-1124. [CrossRef]

36. El-Tabei, A.S.; Hegazy, M.A. Application of the synthesized novel3,6,9,12,15,18,21-heptaoxatricosane-1,23-diyl bis(4-((4-(dimethylamino)benzylidene)amino)benzoate) as a corrosion inhibitor for MS in acidic media. J. Dispers. Sci. Technol. 2014, 35, 1289-1299. [CrossRef]

37. Kubo, J.; Tanaka, Y.; Page, C.L.; Page, M.M. Application of electrochemical organic corrosion inhibitor injection to a carbonated reinforced concrete railway viaduct. Constr. Build. Mater. 2013, 39, 2-8. [CrossRef]

38. Han, P.; He, Y.; Chen, C.; Yu, H.; Liu, F.; Yang, H.; Ma, Y.; Zheng, Y. Study on synergistic mechanism of inhibitor mixture based on electron transfer behavior. Sci. Rep. 2016, 6, 33252. [CrossRef]

39. Abdallah, M.; Hegazy, M.A.; Alfakeer, M.; Ahmed, H. Adsorption and inhibition performance of the novel cationic gemini surfactant as a safe corrosion inhibitor for MS in hydrochloric acid. Green Chem. Lett. Rev. 2018, 11, 457-468. [CrossRef]

40. Chidiebere, M.A.; Oguzie, E.E.; Liu, L.; Li, Y.; Wang, F. Ascorbic acid as corrosion inhibitor for Q235 mild steel in acidic environments. J. Ind. Eng. Chem. 2015, 26, 182-192. [CrossRef]

41. Liu, A.; Tian, H.; Li, W.; Wang, W.; Gao, X.; Han, P.; Ding, R. Delamination and selfassembly of layered double hydroxides for enhanced loading capacity and corrosion protection performance. Appl. Surf. Sci. 2018, 462, 175-186. [CrossRef]

42. Hegazy, M.A.; El-Tabei, A.S.; Ahmed, H.M. Synthesis of nonionic surfactants and their inhibitive action on MS in hydrochloric acid. Corros. Sci. 2012, 64, 115-125. [CrossRef] 
43. Zeng, L.; Zhang, G.; Guo, X.; Chai, C. Inhibition effect of thioureidoimidazoline inhibitor for the flow accelerated corrosion of an elbow. Corros. Sci. 2015, 90, 202-215. [CrossRef]

44. Umoren, S.; Obot, I.; Ebenso, E. Corrosion inhibition of aluminium using exudate gum from Pachylobus edulis in the presence of halide ions in HCl. J. Chem. 2008, 5, 355-364.

45. Gong, W.; Yin, X.; Liu, Y.; Chen, Y.; Yang, W. 2-Amino-4-(4-methoxyphenyl)-thiazole as a novel corrosion inhibitor for mild steel in acidic medium. Prog. Org. Coat. 2019, 126, 150-161. [CrossRef]

46. Hegazy, M.A.; El-Rehim, S.S.A.; Badr, E.A.; Kamel, W.M.; Youssif, A.H. Mono-, di- and tetra-cationic surfactants as MS corrosion inhibitors. J. Surfactants Deterg. 2015, 18, 1033-1042. [CrossRef]

47. Jokar, M.; Farahani, T.S.; Ramezanzadeh, B. Electrochemical and surface characterizations of morus alba pendula leaves extract (MAPLE) as a green corrosion inhibitor for steel in $1 \mathrm{M} \mathrm{HCl}$. J. Taiwan Inst. Chem. Eng. 2016, 63, 436-452. [CrossRef]

48. Odewunmi, N.; Umoren, S.; Gasem, Z. Watermelon waste products as green corrosion inhibitors for mild steel in $\mathrm{HCl}$ solution. J. Environ. Chem. Eng. 2015, 3, 286-296. [CrossRef]

49. Joseph, O.; Fayomi, O.; Adenigba, O. Effect of lecaniodiscus cupaniodes extractin corrosion inhibition of normalized and annealed mild steels in $0.5 \mathrm{M} \mathrm{HCl}$. Energy Procedia 2017, 119, 845-851. [CrossRef]

50. Bedair, M.A.; Soliman, S.A.; Hegazy, M.A.; Obot, I.B.; Ahmed, A.S. Empirical and theoretical investigations on the corrosion inhibition characteristics of mild steel by three new Schiff base derivatives. J. Adhes. Sci. Technol. 2019, 33, 1139-1168. [CrossRef]

51. Musa, A.Y.; Kadhum, A.H.; Mohamad, A.B.; Rohoma, A.B.; Mesmari, H. Electro-chemical and quantum chemical calculations on 4,4-dimethyloxazolidine-2-thione as inhibitor for mild steel corrosion in hydrochloric acid. J. Mol. Struct. 2010, 969, 233-237. [CrossRef]

52. El-Lateef, H.M.A.; Abdallah, Z.A.; Ahmed, M.S.M. Solvent-free synthesis andcorrosion inhibition performance of Ethyl 2-(1,2,3,6-tetrahydro-6-oxo-2-thioxopyrimidin-4-yl)ethanoate on MS in pickling acids: Experi-mental, quantum chemical and Monte Carlo simulation studies. J. Mol. Liq. 2019, 296, 111800. [CrossRef]

53. Peme, T.; Olasunkanmi, L.O.; Bahadur, I.; Adekunle, A.S.; Kabanda, M.M.; Ebenso, E.E. Adsorption and corrosion inhibition studies of some selected dyes as corrosion inhibitors for mild steel in acidic medium: Gravimetric, electrochemical, quantum chemical studies and synergistic effect with iodide ions. Molecules 2015, 20, 16004-16029. [CrossRef]

54. Qiang, Y.; Zhang, S.; Tan, B.; Chen, S. Evaluation of Ginkgo leaf extract as an eco-friendly corrosion inhibitor of X70 steel in $\mathrm{HCl}$ solution. Corros. Sci. 2018, 133, 6-16. [CrossRef]

55. Hegazy, M.A.; Aiad, I. 1-Dodecyl-4-(((3-morpholinopropyl)imino) methyl)pyridin-1-ium bromide as a novel corrosion inhibitor for MS during phosphoric acid production. J. Ind. Eng. Chem. 2015, 31, 91-99. [CrossRef]

56. Qiang, Y.; Zhang, S.; Yan, S.; Zou, X.; Chen, S. Three indazole derivatives as corrosion inhibitors of copper in a neutral chloride solution. Corros. Sci. 2017, 126, 295-304. [CrossRef]

57. Mishra, A.; Verma, C.; Lgaz, H.; Srivastava, V.; Quraishi, M.A.; Ebenso, E.E. Synthesis, characterization and corrosion inhibition studies of N-pheny-l-benzamides on the acidic corrosion of mild steel: Experimental and computational studies. J. Mol. Liq. 2018, 251,317-332. [CrossRef]

58. El-Din, M.R.N.; Al-Sabagh, A.M.; Hegazy, M.A. Study of the inhibition efficiency for some novel surfactants on the MS (Type H-11) pipelines in $0.5 \mathrm{M} \mathrm{HCl}$ solution by potentiodynamic technique. J. Disper. Sci. Technol. 2012, 33, 1444-1451. [CrossRef]

59. Kumar, R.; Chahal, S.; Kumar, S.; Lata, S.; Lgaz, H.; Salghi, R.; Jodeh, S. Corrosion inhibition performance of chromone-3-acrylic acid derivatives for low alloy steel with theoretical modeling and experimental aspects. J. Mol. Liq. 2017, 243, 439-450. [CrossRef]

60. Khadom, A.A.; Abd, A.N.; Ahmed, N.A. Xanthium strumarium leaves extracts as a friendly corrosion inhibitor of low MS in hydrochloric acid: Kinetics and mathematical studies. S. Afr. J. Chem. Eng. 2018, 25, 13-21.

61. Labena, A.; Hegazy, M.A.; Horn, H.; Müller, E. Sulfidogenic-corrosion inhibitory effect of cationic monomeric and gemini surfactants: Planktonic and sessile diversity. RSC Adv. 2016, 6, 42263-42278. [CrossRef]

62. Li, H.; Yu, C.; Chen, R.; Li, J.; Li, J. Novel ionic liquid-type Gemini surfactants: Synthesis, surface property and antimicrobial activity. Colloids Surf. A Physicochem. Eng. Asp. 2012, 395, 116-124. [CrossRef] 
63. Labena, A.; Hegazy, M.A.; Horn, H.; Müller, E. The biocidal effect of a novel synthesized gemini surfactant on environmental sulfidogenic bacteria: Planktonic cells and biofilms. Mater. Sci. Eng. C 2015, 47, 367-375. [CrossRef]

64. Pillai, P.; Pal, N.; Mandal, A. Synthesis, characterization, surface properties and mi-cellization behaviour of imidazolium-based ionic liquids. J. Surfactants Deterg. 2017, 20, 1321-1335. [CrossRef]

65. El-Tabei, A.S.; Hegazy, M.A.; Bedair, A.H.; Sadeq, M.A. Synthesis and inhibition effect of a novel Tri-cationic surfactant on MS corrosion in $0.5 \mathrm{M} \mathrm{H}_{2} \mathrm{SO}_{4}$ solution. J. Surfactants Deterg. 2014, 17, 341-352. [CrossRef]

66. Labena, A.; Hegazy, M.A.; Kamel, W.M.; Elkelish, A.; Hozzein, W.N. Enhancement of a cationic surfactant by capping nanoparticles: Synthesis, characterization and multiple applications. Molecules 2020, 25, 2007-2025. [CrossRef] [PubMed]

67. Kamboj, R.; Singh, S.; Chauhan, V. Synthesis, characterization and surface properties of N-(2-hydroxyalkyl)-N'-(2-hydroxyethyl)imidazolium surfactants. Colloids Surf. A Physicochem. Eng. Asp. 2014, 441, 233-241. [CrossRef]

68. Shaban, S.M.; Saied, A.; Tawfik, S.M.; Abd-Elaal, A.; Aiad, I. Corrosion inhibition and Biocidal effect of some cationic surfactants based on Schiff base. J. Ind. Eng. Chem. 2013, 19, 2004-2009. [CrossRef]

69. Badr, E.A. Inhibition effect of prepared cationic surfactant on the corrosion of carbon steel in $1 \mathrm{M} \mathrm{HCl}$. J. Ind. Eng. Chem. 2014, 20, 3361-3366. [CrossRef]

70. Aiad, I.; El-Sukkary, M.M.; Soliman, E.A.; El-Awady, M.Y.; Shaban, S.M. Inhibition of mild steel corrosion in acidic medium by some cationic surfactants. J. Ind. Eng. Chem. 2014, 20, 3524-3535. [CrossRef]

(C) 2020 by the authors. Licensee MDPI, Basel, Switzerland. This article is an open access article distributed under the terms and conditions of the Creative Commons Attribution (CC BY) license (http://creativecommons.org/licenses/by/4.0/). 